Muscat, Sultanate OF OMan)

Anaïs MARRAST ${ }^{1}$, Philippe BÉAREZ ${ }^{1}$, Emilie BADEL ${ }^{2}$, Lapo Gianni MARCUCCI ${ }^{3}$. the inhabitants clearly exploited the different nearby inshore environments: coastal open water,
reefs, estuary and mangrove. Moreover, the high fish richness (69 genera at RH-6; 35 genera at the inhabitants clearly exploited the different nearby inshore environments: coastal open water,
reefs, estuary and mangrove. Moreover, the high fish richness (69 genera at RH-6; 35 genera at RH-5) indicates that both sites could have been occupied on a year-round basis.

Ra's al-Hamra 6 (RH-6) and Ra's al-Hamra 5 (RH-5) are two of the most important Neolithic coastal sites in the Sultanate of Oman. Located in the capital Muscat, they have supplied an important corpus of fish bones and revealed a high taxonomic richness in the different assemblages. The results provided information on fishing practices that held an important role in the subsistence strategies of the inhabitants during the two millennia of occupation $\left(6^{\text {th }}-4^{\text {th }}\right.$ millennia BC). Pelagic species (jacks and kawakawa/tunas) were largely dominant throughout both occupations, calling into question the interpretation of inshore or offshore fishing; these fish could have been caught with a hook-and-line or by setting nets at a reasonable distance from the coast. However, the inhabitants also had to supplement this subsistence by catching demersal fish and small fish, caught from the cliff, in the estuary or the mangrove. At both sites, RH-5) indicates that both sites could have been occupied on a year-round basis.

\title{
INTRODUCTION
}

Many shell middens have been identified in South Eastern Arabia for the Middle Holocene (7th-4th millennia), and the important economic role of aquatic resources is well established (e.g., Beech 2004; Biagi 1994, 2006). Fishing does appear to have been important to these

populations, described as fisher-hunter-gatherer communities (Charpentier 2008; Cleuziou and 
26 been analysed and published (Cartwright 2004; Uerpmann and Uerpmann 2003; Wilkens 27 2005).

28 The ancient shell midden of Ra's al-Hamra 6 (RH-6) and the more recent one of Ra's al29 Hamra 5 (RH-5) are two of the most important Neolithic sites in the Gulf of Oman (Figure 1). 30 The total area of each of the two sites is estimated at approximately $3500 \mathrm{~m}^{2}$ for RH-6 and 3000 $31 \mathrm{~m}^{2}$ for RH-5. Several successive campaigns have highlighted a deep stratigraphy of almost $2 \mathrm{~m}$ 32 with numerous finds, including animal remains, fishing gear, and burials (Biagi 1987, 1999; 33 Biagi and Maggi 1987; Biagi and Nisbet 1992; Biagi and Salvatori 1986; Coppa et al. 1985; 34 Marcucci et al. 2011, 2014; Salvatori 2007). The first fish bone analyses at Ra's al-Hamra were carried out by Biagi and Travers (1985), followed by more recent studies by Uerpmann and chronology of the site.

Figure 1. (A) Location, altitudinal and bathymetric mapping of the Qurum mangrove and the Ra's al-Hamra's cape, with location of the archaeological sites; (B) Map of the excavated sectors of RH-6 (Marcucci et al., 2014, fig. 1.A.); and (C) Map of the excavated sectors of lagoon environment exploitation, although with very different patterns of fishing: primarily

The latest investigations on the Arabian Sea coastal fringe include new fish bone studies sharks at SWY-1 (Marrast, Béarez, and Charpentier 2020), and sardines, mullets, and juvenile fish at RWY-1 (Berger et al. 2020). 
Based on recent excavations at RH-6 and RH-5 (Marcucci et al. 2011, 2014; Marcucci,

51 Badel, and Genchi 2021), this paper presents the results from new fish bone analyses (Marrast 52 2020) and sheds light on Neolithic fishing practices in the capital area of Muscat (southern coast 53 of the Gulf of Oman).

\section{Environmental setting}

The study area is located at the southeastern end of the sandy beaches in the Al Batinah

Region, where the Qurum mangrove swamp stands, and where the rocky shores of Muscat

begin. The settlements of Ra's al-Hamra are located on the eastern edge of the Qurum Natural

Reserve in the district of Qurum (Figure 1A). In this area, twelve settlements have been reported and four have been excavated (Durante \& Tosi 1977; Uerpmann and Uerpmann 2003). Today,

61 RH-6 is about 600 m away from the sea, and RH-5 is on top of the rocky headland overhanging the Gulf of Oman. But, it is important to note that at the end of the fifth millennium BC, which corresponds to the end of RH-6 and the beginning of RH-5 occupations, a higher sea level (+ $1 \mathrm{~m})$ than today has been identified in the northern coast of Batinah (Vita-Finzi 1982; Berger et al. 2005, 56). The sites are surrounded by a multifaceted natural setting which allowed Neolithic communities quick access to the Qurum mangrove, the shallow sea, the estuary, the sandy 67 beach, and even the rocky shoreline along the cliffs. In these distinct environments, ancient 68 fishermen had access to various animal resources, such as seashells, crabs, and, of course, fish 69 (Biagi 1987; Biagi and Maggi 1987; Biagi and Travers 1985; Tosi 1975). Within the Gulf of 70 Oman, the Omani Coast is influenced by monsoonal winds; it is also indirectly affected by the 71 Arabian Sea upwellings, which bring nutrient rich cold waters to the surface (Al-Azri et al. 72 2014). 
Both sites offer insight into the continuous occupation of this area from the middle of the sixth millennium to the end of the fourth millennium BC. This occupation took place during the Holocene Humid Period, which had a stronger summer monsoon than today, illustrating a climatic optimum induced by a higher latitude position of the Intertropical Convergence Zone (ITCZ) (Fleitmann et al. 2007; Lézine et al. 2017; McClure 1976). This situation was probably favorable for the extension of mangrove and lagoon ecosystems, as confirmed by the numerous Terebralia palustris shells and Avicennia sp. charcoal fragments radiocarbon dated from this period (Berger et al. 2013; Tengberg 2005).

The occupation of RH-6 ranges from the sixth millennium to the middle of the fifth

millennium $\mathrm{BC}$, but the graveyard is currently dated to the beginning of the fourth millennium BC (Biagi 2006; Zazzo et al. 2016). Dating of the settlement makes RH-6 the oldest site in the archaeological sequence of Qurum. Recent excavations identified several sectors (Marcucci et al. 2014): Sector A (eastern edge of the midden); B (post-occupation burials of RH-6 that were contemporaneous with the occupation of RH-5); C/TT-Z (eastern edge of the midden); and 90 Trench North (northern edge of the midden) (Figure 1B). Several post holes and hearths, 91 indicating the presence of huts and living structures, were uncovered. Sector C/TT-Z, a trench with a maximum depth of about $1.75 \mathrm{~m}$, was selected for bioarchaeological sampling. This trench provided a lot of organic material: seeds and charcoal fragments, seashells, and remains of terrestrial and marine mammals, sea turtles (Frazier et al. 2018), and fish. Each stratigraphic unit (SU) was sieved using $3 \mathrm{~mm}$ and $1 \mathrm{~mm}$ mesh. Thirty-two samples of charcoal fragments, shells, and human bones were selected for ${ }^{14} \mathrm{C}$ dating (Zazzo et al. 2016). The same protocol was then applied to the Trench North excavation. Six periods were defined in Sector C/TT-Z and four in Trench North (Marcucci et al. 2014). 
The occupation of RH-5 ranges from the end of the fifth to the end of the fourth millennium

101 BC (Biagi 1994; Biagi and Nisbet 2006; Zazzo, Munoz, and Saliège 2014). During recent 102 excavations, the study area was divided into six sectors (Figure 1.C). Sector B2, which is the 103 subject of this study, dates from 3910-3640 cal BC (LTL12826A: 4943 \pm 45 BP, IntCal05) 104 (Marcucci 2015) and covers an area of $25 \mathrm{~m}^{2}$, under an archaeological deposit 10-20 cm deep; 105 here, 200 post holes were detected related to six living structures and associated with six 106 probable waste pits. Four phases were defined in this sector with multiple remains of non107 permanent living structures in connection with hearths, storage, and dump pits, and the many 108 intersections of these structures, which suggest intensive and prolonged occupation of the site. 109 Each SU was sieved using a $1 \mathrm{~mm}$ mesh (Marcucci et al. 2011; Marcucci, Badel, and Genchi 110 2021).

115 Travers (1985) undertook an exploratory study on material taken from the first excavation (1981). The in situ occurrence of small pelagic species, such as sardines (Clupeidae) and anchovies (Engraulidae), was noted, as was the presence of large pelagic species, such as tunas 118 (Thunnus spp., Scombridae) and numerous coastal fishes from rocky or sandy-mud bottoms, and many marine catfishes (Ariidae). Another study by Uerpmann and Uerpmann (2003, table 9.7) (51 NISP) questioned some of the previous identifications (Table 1). They obtained only 121 one marine catfish specimen but 22 identified specimens belonging to jacks and trevallies 122 (Carangidae), and 23 identified specimens from tunas. A complementary study was 
124 presence of different pelagic fish, such as several scombrids and numerous bentho-demersal 125 fish taxa. In all these studies, the main taxa identified were similar (i.e., Scombridae, 126 Carangidae, Sparidae, Serranidae, Lethrinidae).

Table 1. Table synthetizing the main results from previous studies on the fish bone remains from RH-6 and RH-5 (for Uerpmann and Uerpmann 2003, NISP have been calculated from identified Actinopterygii and Chondrichthyes), and modern data of artisanal fishing from the governorate of Muscat for 2009-2018 (M.A.F. 2018)

indicated that fishing activities were oriented mainly toward the exploitation of medium-sized tunas (NISP $=7596)$, and jacks/trevallies (NISP $=4065)$. The exploitation of demersal taxa, such as breams (Sparidae), emperors (Lethrinidae), or parrotfishes (Scaridae), was secondary.

138 However, they noted the occurrence of a large grouper (Epinephelus sp.), estimated at a minimum of $150 \mathrm{~cm}$, and a shark represented by a vertebra of $40 \mathrm{~mm}$ in diameter, which is very 140 large. In contrast, they also indicated the presence of a high number of small fish in the $1 \mathrm{~mm}$ samples (NISP $=402$ of 3920 remains counted).

\section{MATERIAL AND METHODS}

The material studied here came from Sector C/TT-Z and Trench North for RH-6, and from

Sector B2 for RH-5 (Figure 1B-C). For the RH-6 material, each stratigraphic unit was sieved using $3 \mathrm{~mm}$ and $1 \mathrm{~mm}$ mesh. For the RH-5 material, each SU was sieved using $1 \mathrm{~mm}$ mesh.

Cut marks were absent, and all burning marks were reported. However, due to the high fragmentation and the number of remains, we did not record the fragmentation pattern. To 
149 facilitate the reader's understanding, the results are presented by period; more detailed results 150 are available in Marrast (2020).

151 For the identification of the fish remains, we used the fish skeletons reference collection of 152 the National Museum of Natural History of Paris, which countains for ca. 900 specimens 153 representing ca. 500 species of Indo-Pacific fishes. Fish remains were identified at the most 154 precise taxonomic level (species), but due to the high fragmentation of the remains, the 155 identification was done mainly to genus or family level. Occasionally, we used higher taxa, such as the superfamily Sparoidea, which here includes all species of the families Sparidae, 157 Lethrinidae, and Nemipteridae, as they have very similar vertebrae or teeth which were numerous in the small material and difficult to differentiate.

Grouping of fish skeletal elements is adapted from Wheeler and Jones (1989): cranial bones 160 (neurocranium and branchiocranium elements); vertebrae; and others (fin elements, scales, and scutes). Fish systematic nomenclature follows Fricke, Eschmeyer, and Van der Laan (2021).

As for fish habitat and ecology, we followed the information from Randall (1995), and FishBase (Froese and Pauly 2021). To simplify our interpretations, the fishes have been classified into two main categories: pelagic fish, which include all species living in the water column (whether coastal or open sea, up to $200 \mathrm{~m}$ deep), and demersal fish, which are associated with coastal substrates. To discuss the seasonality of fishing activities and site occupation, we used information from the Ministry of Agriculture and Fisheries (M.A.F.) of the Sultanate of 168 Oman, which provides data on monthly artisanal fisheries landings for the governorate of Muscat (M.A.F. 2013, 2015, 2016, 2018).

We mainly use the term NISP (Number of Identified Specimens), which corresponds to the number of fish remains identified to at least superorder level for Chondrichthyes (Batoidea for 
174 Siluriformes, Tetraodontiformes). We also use the term WISP (Weight of Identified Specimens)

175 for the weight of the identified bone remains.

176 We used the classical approach of comparative anatomy and chose to estimate the live weight

177 of the fish, rather than its size, because this seems to be a better indicator of the amount of flesh

178 the fish can provide. The live weights we provide are weight visual estimates, made by direct

179 comparison with specimens from the fish reference collection of known live weight and length

180 data, not reconstructions using osteometric models. The estimate of the MNI (Minimum

181 Number of Individuals) was performed on the main taxa (species or genus level) despite the

182 high number of vertebrae, which sometimes made it very difficult. MNI was estimated by

183 counting the most frequent anatomical element of a given species after considering laterality

184 and size (i.e., MNI of combination; Poplin, 1976). Several species of jacks and trevallies present

185 in the study area have characteristic swollen bones (hyperostosis) on the occipital crest or 186 cleithrum, which, due to their good preservation, were often found and used for the estimation 187 of the MNI.

188 In order to compare results from different chronological periods, chi square tests were 189 performed on the corresponding NISP to detect the dependency between two faunal 190 assemblages, and therefore the associated fishing patterns (Chenorkian, 1996). Tests were 191 performed on each pair of assemblages from two successive periods $\left(\mathrm{H}_{0}\right.$ : The two relative 192 proportions do not differ significantly). To respect the test conditions $(n>5)$ for each test, only 193 the most important fish families (between 5 or 7 , depending on the assemblages) were tested.

\section{RESULTS}

\section{The RH-6 site}

Since Trench North is more representative of the beginning of the occupation and Sector $\mathrm{C} / \mathrm{TT}-\mathrm{Z}$ is more representative of the end, we will present the results in this order. The 
equivalence between the periods in the two sectors is adapted from Marcucci (2015: table A2.13). For ease of presentation, we discuss the results for the main families and mostly at the genus level, except for Thunnini. All the species identifications can be found in supplemental files $1-3$.

\section{Trench North $-3 \mathrm{~mm}$}

For Trench North, located at the northern edge of the shell midden, vertebrae were the most abundant $(66.5 \%$ of the material anatomically identified), followed by cranial elements (26.5\%), and other post-cranial elements (7\%). The dentary was the most represented cranial bone (NISP $=528)$, followed by the premaxilla $($ NISP $=353)($ Table 2$)$. These jaw bones are among the strongest bones in most teleosteans (bony fish) and consequently have a very good conservation rate (Wheeler and Jones 1989,90 ). Still, there is a major imbalance between the remains of the skull and the spine because the vertebrae are thicker than the skull bones and therefore better preserved.

Table 2. Element distribution on the two sites according to the sector studied and the sieving mesh size (Chondr. $=$ Chondrichthyes)

A total of 9116 fish bones (NISP) were identified. Most of this material corresponded to the beginning of the occupation of RH-6, i.e., periods 1-4 of Sector C/TT-Z. In Trench North, four periods were defined. However, as periods 3 and 4 were poor in fish (NISP $=9)$ these results were not included in the discussion. Period 1 is taxonomically rich ( 32 families, 51 genera), associated with a high NISP (4908). Period 2, with a lower NISP (4208), is less taxonomically rich (23 families, 38 genera) (Figure 2A). 

periods

Chi square tests were performed between the assemblages but did not reveal any significant differences $\left(X^{2}: 6.6397, p>0.1\right.$, df: 4) (Figure 3A; Table 3). Pelagic fish represent more than $91 \%$ of the assemblage NISP for the two periods, with trevallies (Carangoides spp.) as the main taxon (20\%). Kawakawa (Euthynnus affinis) and jacks (Caranx spp.) were of similar importance throughout the site's occupation (15.5\% and $12 \%)$, as was the golden trevally (Gnathanodon speciosus) (3.6\%), while tunas seem to be the least important of the pelagic fishes; the two species accounting for just $5-6 \%$. The contribution of demersal fish, mainly represented by different seabreams, emperors, and groupers (Serranidae), was very low (9\%) (Table 3).

Figure 3. Illustration of the main taxa distribution (NISP).

(A) RH-6, Trench North, $3 \mathrm{~mm}$; (B) RH-6, Sector C/TT-Z, $3 \mathrm{~mm}$. Made with ACACIA

$$
\text { (Nourissier, Nocus, and Dufraisse, 2010) }
$$

Table 3. Zooarchaeological fish remains from RH-6, Trench North, $3 \mathrm{~mm}$, according to periods in NISP, \% of NISP and WISP (g). Other pelagic = 12 families (Supplemental file 1); Other demersal $=19$ families (Supplemental file 1).

The mean weight of the caught fish varied between periods. Indeed, while the tuna mean weight for period 1 is $7 \mathrm{~kg}$, it falls to $4.5 \mathrm{~kg}$, and has a greater distribution, in period 2 (Figure 4A). In contrast, jacks are larger in period $2(2.5 \mathrm{~kg}$ versus $1 \mathrm{~kg}$ in period 1$)$, while kawakawas, and trevallies weigh in at 3 to $3.5 \mathrm{~kg}$ for both periods (Figure 4B-D). However, the NISP of 
249 kawakawa and jacks must be considered against the MNI (Table 4). Most of the kawakawa 250 bones are vertebrae, which have high conservation rates because of their extremely robust 251 constitution. On the other hand, many cranial elements of jacks were found, increasing their 252 MNI. The difference in proportions between kawakawa and tunas is less when measured by 253 MNI than by NISP.

Figure 4. Illustration of the estimated weight of each main pelagic taxa from the richest RH-6 periods (P: Period), both sectors (TN: Trench North, C-TTZ: Sector C TT-Z). Min: Minimum, Max: Maximum, Q: Quartile. (A) Thunnus spp; (B) Euthynnus affinis; (C) Carangoides spp.; (D) Caranx spp.

Table 4. MNI estimates of the main pelagic taxa at RH-6, $3 \mathrm{~mm}$, according to periods and comparison with the NISP

$\underline{\text { Sector } C / T T-Z-3 \mathrm{~mm}}$ cranial bones (Table 2).

For Sector C/TT-Z, vertebrae were also the most abundant element ( $62 \%$ of the material anatomically identified), followed by cranial elements (30\%), and other post-cranial elements (8\%). Jaw bones, with 508 premaxillae and 496 dentaries, were the most frequently represented

A total NISP of 8489 have been determined, but abundance of fish bones was very disparate from one period to another. Fish bones were much less abundant in the four oldest periods than in the two most recent ones (Figure 3B). Taxonomic richness has increased over time (Figure 2B), in a trend that appears to be roughly independent of the NISP. Richness peaked in period 6 (26 families, 52 genera), while its NISP (3464) was lower than in period 5 (4109). 
In this sector, pelagic fish taxa were also dominant (Figure 3B, Table 5). Jacks were the main taxa $(18 \%$ of the total assemblage), followed by trevallies (11.5\%), and kawakawas $(10 \%)$. Chi square tests were performed between all pairwise assemblages, with the exception of period 2 due to its small sample size but did not reveal any significant differences between periods 3 and 4 (Figure 3B) $\left(\chi^{2}: 12.93, p>0.01\right.$, df: 4$)$. On the contrary, periods 4 and 5 exhibited a strong statistical difference in faunal composition, supporting a genuine increase in the proportions of scombrids (from $25 \%$ to $21 \%$ ).

Table 5. Zooarchaeological fish remains from $\mathrm{RH}-6$, Sector C/TT-Z, $3 \mathrm{~mm}$, according to periods in NISP, \% of NISP and WISP (g). Other pelagic = 5 families (Supplemental file 1); Other demersal $=24$ families (Supplemental file 1)

In Sector C/TT-Z, an increase in MNI is associated with the end of occupation. Indeed, periods 5 and 6 were represented by 386 and 294 main pelagic fishes, much more than in previous periods (Table 4).

Mean fish weights were estimated for the two most recent periods (Figure 4), periods 5 and 6, because their sample sizes were large enough to allow comparison with the Trench North periods. For kawakawa and tunas, specimens were bigger in period 6 with a mean weight reaching $4 \mathrm{~kg}$ (versus $3.1 \mathrm{~kg}$ ) and $5 \mathrm{~kg}$ (versus $3.5 \mathrm{~kg}$ ), respectively (Figure 4A-B). Conversely, for jacks and trevallies, there was a decrease in the mean weight at the end of RH-6 occupation, 
with the mean weight of jacks decreasing from $2 \mathrm{~kg}$ to $700 \mathrm{~g}$, and that of trevallies decreasing slightly from $3 \mathrm{~kg}$ to $2.6 \mathrm{~kg}$ (Figure 4C-D).

\section{$\underline{\text { Sector C/TT-Z - } 1 \text { mm sampling }}$}

Here, the results are presented only for periods 2 to 6 of Sector C/TT-Z. Two samples were

Table 6. Zooarchaeological fish remains from RH-6, Sector C/TT-Z, $1 \mathrm{~mm}$ in NISP and \% of NISP by period. Other pelagic $=9$ families $($ Supplemental file 1); Other demersal $=13$ families (Supplemental file 1) vertebrae (95\%), cranial elements (4.5\%), and other elements (0.5\%) (Table 2). 

RH-6, Sector C/TT-Z, $1 \mathrm{~mm}$ (Periods 2, 3, 4, 5, 6) - RH-5, Sector B2, $1 \mathrm{~mm}$ (Phases 2, 3,

\section{The $\mathrm{RH}-5$ site}

In Sector B2, all zooarchaeological material was recovered by sieving with a $1 \mathrm{~mm}$ mesh. Other demersal $=20$ families (Supplemental file 1)

There was a discrepancy in the anatomical distribution of vertebrae (95\%), cranial elements (4.5\%), and other elements (0.5\%) (Table 2). A total of 8406 specimens were identified, weighing $92 \mathrm{~g}$ (Table 7). Assemblage abundance was variable over time and due to low specimen numbers in phase 1, these data are excluded from the interpretation of the results.

\section{Table 7. Zooarchaeological fish remains from RH-5, Sector B2, $1 \mathrm{~mm}$, according to periods in NISP, \% of NISP and WISP (g). Other pelagic = 7 families (Supplemental file 1);}

Since the beginning of occupation, richness was relatively high. For phase 1, despite a very low NISP (32), high richness was noted (7 families, 7 genera). It reached a peak in phase 3 (27 families, 33 genera), with the highest NISP (6640) counted. During phase 4 (15 families, 17 genera), there was a decrease in NISP (1492) (Figure 2D).

Chi square tests were performed between the assemblages and revealed significant proportional differences in faunal composition between phases 2 and $3\left(X^{2}: 55.84, p<0.001\right.$, df: 4). These changes are driven by the observed increases or decreases in several taxa. In phase 2, carangids, including bigeye scads, were the most abundant taxon, representing $44.5 \%$ of identified specimens (Table 7, Figure 5). They decreased to $36 \%$ in phase 3 , replaced by sardines (55\% in phase 3). For the phases 3 and 4, Chi square tests did not reveal significant 
349 proportional difference in faunal composition $\left(x^{2}: 6.68, p<0.001\right.$, df: 5). Indeed, the sardines

350 contributed a similar proportion to the assemblage in phase 4. Other pelagic (mullets, 351 barracudas) and demersal (Sparoidea) taxa declined in abundance over time.

352 The assemblages were composed mainly of small vertebrae, which complicated the MNI 353 calculation. Estimating precise live weight from small bones is challenging, but most of the 354 RH-5 fish (scads, sardines, mullets, Indian mackerel) belonged to the $150 \mathrm{~g}$ weight category. 355 No fish larger than $5 \mathrm{~kg}$ were recorded from our study at RH-5. the Ra's al-Hamra sites, although the materials analyzed came from distinctly separate sectors.

\section{Taphonomic remarks}

Several trends clearly emerged concerning different aspects of the fishing economy across

\section{Discussion}

The NISP of kawakawa and jacks must be considered alongside the MNI (Table 4). Most of the kawakawa bones are vertebrae, which have high conservation rates because of their extremely robust constitution. On the other hand, many cranial and hyperostosic elements of jacks and trevallies were found, which increases their MNI. The difference in proportions between kawakawa and jacks, therefore, no longer appears to be as great with the MNI as with the NISP. found, fish were probably complete and fresh when brought to the site. Apart from gutting, they were probably not processed before consumption. As for the burn marks on the bones, very few

As the cranial elements were highly represented in each SU and no traces of butchery were were noticed on both sites and no burning pattern could be discerned. The bones could be 
completely burnt, indicating that they had probably simply been thrown into the fire after the

374 fish had been consumed.

\section{Fishing patterns}

Our results indicate slight changes through time between the two sites. The RH-6 fishermen concentrated their efforts on catching medium-sized pelagic fish, comparable with previous RH-5 results. At both sites, pelagic fish accounted for more than $80 \%$ over time (Tables 1, 3, 5), illustrating a subsistence strategy probably adapted to a marine environment rich in pelagic fish. However, when considering the proportions of the two main families of pelagic fish, the fishing pattern of the late RH-6 occupation (Period 6) and that of RH-5 (Table 1; Uerpmann and Uerpmann, 2003) appeared to be highly different $\left(X^{2}: 2934.68, p<0.001\right.$, df: 6$)$. The inhabitants of RH-5 seem to have concentrated their efforts on catching different scombrids. This change may represent different cultural choices in fishing strategies.

The results from the $1 \mathrm{~mm}$ mesh fraction highlighted the importance of small fish, with a high number of remains counted at both sites (Tables 6, 7). It is particularly important to note here the very high proportion of vertebrae $(95 \%)$ in the $1 \mathrm{~mm}$ fraction material at both sites. The preservation of vertebrae is often better than that of cranial bones, but this is even more true in the case of small fish. Based on the study of this material, fishing patterns appear to be very specific to each site (RH-6-P6 and RH-5-Ph3, $x^{2}$ : 1400.76, $p<0.001$, df: 6 ). Sardines constituted $45 \%$ of the fish remains at the beginning of RH- 6 occupation, but by the end constituted $70 \%$ of the faunal assemblage. At RH-5, scads are abundant at the beginning of occupation (36\% in phase 2 , while sardines occupied $35 \%$ ), but this pattern is reversed at the end of the occupation (sardines 58\% and scads 32\%). For RH-5, however, consideration of WISP provides a more nuanced understanding of the results. Indeed, if sardines, scads, and mackerel are dominant based on NISP, kawakawas, barracudas, and jacks/trevallies are the best 
represented according to the WISP, especially jacks (Caranx spp.). Demersal fish were rare at RH-5, and it is interesting to note that most of the fish in Sector B2 were represented by 400 specimens weighing less than $150 \mathrm{~g}$.

Nowadays, artisanal fishing, by line, troll, or net, provides landings composed mainly of 403 large pelagic species, such as longtail tuna (Thunnus tonggol), yellowfin tuna (Thunnus 404 albacares), kawakawa (Euthynnus affinis), large jacks/trevallies (Caranx spp. and Carangoides 405 spp.), and Talang queenfish (Scomberoides commersonnianus). An important part of the 406 fishery, however, consists of small pelagic fish, such as sardines (Clupeidae), Indian mackerel 407 (Rastrelliger kanagurta), and mullets (Mugilidae) (Table 1, M.A.F. 2018). However, while the 408 species fished today were already present on the two archaeological sites, two pelagic species, 409 the Talang queenfish and the Narrow-barred Spanish mackerel (Scomberomorus commerson), are absent or only very occasionally present in the mid-Holocene catch (see Supplemental file

411 1). Moreover, the proportions are very different today, with pelagic fish representing more than $41280 \%$ of the catch at RH- 6 and RH-5, compared to $70 \%$ in the modern catch.

$414 \quad$ Inshore or offshore?

415 Despite the occurrence of medium-sized pelagic fish in several sites throughout the Persian 416 Gulf and Gulf of Oman for the Neolithic period, such as Delma (Lidour and Beech 2019), Akab 417 (Lidour et al. 2020), Dosariyah (Uerpmann and Uerpmann 2018), and Khor Milkh (Uerpmann 418 and Uerpmann 2003), the sites of Ra's al-Hamra appear to be distinctive given the high 419 proportion of these fish in their faunal material.

420 The abundance of tuna and other pelagic fish raises questions about the existence of offshore 421 fishing in the Neolithic sites of the Gulf of Oman. Since the first studies, interpretations have 
and jacks/trevallies (Biagi et al. 1984; Biagi and Nisbet 1992; Uerpmann and Uerpmann 2003 : 198). The terminology of fishing areas was clarified by Pickard and Bonsall (2004) and adjusted by Béarez et al. (2016) who added water depth as an important parameter. We follow the latter to denote an inshore fishery as one that is conducted in the inshore and nearshore zone (down to $30 \mathrm{~m}$ depth), an offshore fishery as one that is conducted in deeper waters but within sight of land $(<5 \mathrm{~km})$, and an open sea (deep-sea) fishery as one that is conducted out of sight of land.

Although jacks, trevallies, tunas and kawakawa are pelagic, these species can approach relatively close to the coast (Anderson 2013; Collette 2001). Tunas and other scombrids are pelagic fish known to form large, sometimes multi-species schools of thousands of individuals (Collette and Nauen 1983), a behavior which is also observed at a lesser scale in many carangids (scads and young to small adult trevallies and jacks). These open water schools can be observed by fishermen from the coast, especially when sea birds fly over them (Cartwright 2004; Lidour et al. 2020, fig. 7.A). Until recently, fishermen used small rafts or boats, such as shasha, to join a school of tunas, once sighted, and then deployed hook-and-lines or nets to catch them. These small boats are mainly made of date leaves and date palm fibers, which provide buoyancy (AlMarshudi and Kotamaga 2006; Goddard 1985; Johnson 2016; Uerpmann and Uerpmann, 2003, 198-199). Similar, frail embarcations could have been made during the Middle Holocene with materials collected in the vicinity of the Ra's al-Hamra sites, such as Mazari palm (Nannorrhops ritchieana), common reed (Phragmites australis), or cattail (Typha spp.) (Biagi et al. 1984; Biagi and Nisbet 1999; M. Tengberg, pers. comm.). Stronger and sewn vessels are only attested for the third millennium (Cleuziou 2003; Vosmer 2019). As for the ropes of the lines and nets, they may also have been made from Mazari palm; indeed, ropes found at the Shahi Tump site (Iran, fourth millennium BC) were made from this species (Thomas et al. 2012). In addition, fishing cordage has traditionally been made from this species along the Omani Coast 
(Richardson and Dorr 2003); it is favored by fishermen because its strength is increased when wet. Finally, on both RH-6 and RH-5 sites, different shell-hooks and sinkers have been recovered (Biagi, 1987; Marcucci et al., 2011, 2014). mother-of-pearl hook, to catch voracious scombrids (Uerpmann and Uerpmann 2003, 198). The casting of nets from boats is suggested by the presence of large net sinkers, but this practice was probably difficult due to the vulnerability of their frail boats; also, this fishing technique may have been particularly dangerous (Lidour et al. 2020; Uerpmann and Uerpmann 2003, 199). Furthermore, it is possible to fish tuna from shore; indeed, this practice is conducted today for sport (Karachle, Dimarchopoulou, and Tsikliras 2020). spp.) in our studies and those of Uerpmann and Uerpmann (2003), which limits the robustness of the interpretations. Normally, yellowfin tuna can reach larger sizes than the longtail tuna. However, at both archaeological sites, yellowfin tunas appear to be smaller than longtail tuna. Small schools of small tunas probably approached the coast on their own, while larger individuals remained offshore. In addition, kawakawa is the main scombrid found at both sites. It is known that among the schools of kawakawa targeted by fishermen, small tuna specimens may also have been present (Uerpmann and Upermann 2003, 199), so the mixed scombrids fishery may well have been inshore. Fishermen would only need a glittering hook, such as a was probably difficult due to the vulnerability of their frail boats; also, this fishing technique

Large individuals of carangids can currently be found living solitary or in small groups along the coast (Grandcourt 2012; Grandcourt et al. 2004). In the Ra's al-Hamra material, three genera are important: Carangoides, Caranx, and Gnathanodon. The golden trevally (G. speciosus) is often associated with deep reefs and deep lagoons (Grandcourt et al. 2004). As they represent 
473 the main family at RH-6, their presence could be connected with the numerous small line 474 sinkers or the many complete or fragmented hooks found at RH-6 in different stages of manufacture (Biagi 1999). This could indicate a specialization in hook-and-line fishing. However, the large size of some sinkers (Durante and Tosi 1977) may suggest the use of big nets in open water, or fish traps (gargour in Arabic) (Uerpmann and Uerpmann 2003).

While offshore navigation is attested for the Neolithic of the Arabian Peninsula in the Persian

Gulf, with the occupation of islands $10 \mathrm{~km}$ from the coast and the presence of bitumen (Beech

2004; Beech et al. 2016; Carter and Crawford 2010; Lidour et al. 2020), and in Oman with the occupation of Masirah Island (Charpentier et al. 2013), it is not clear whether the fish assemblage reflects offshore fishery. Indeed, previous studies have shown that the presence of scombrids is not necessarily a sign of this activity (Anderson 2013; Béarez, Gay, Lunniss 2012). As most of the species identified at RH-6 and RH-5 are found close to the coast $(<5 \mathrm{~km})$, and there is an absence of large pelagic species such as Indo-Pacific sailfish (Istiophorus platypterus) or large tunas $(>10 \mathrm{~kg})$, this might suggest inshore fishery. The presence of dolphins and whales at both sites could be an indication of offshore fishing, but their presence is too sporadic (NISP: 46 small dolphin, 34 big dolphin, and 31 small whale remains at RH-5) to indicate systematic fishing activity; however, scavenging of beached carcasses cannot be ruled out (Uerpmann and Uerpmann 2003).

\section{Estuary and mangrove exploitation}

In the underwater environment of Ra's al-Hamra, many demersal species could be fished, such as emperors, groupers, snappers, seabreams, and even parrotfish and porcupinefish, all of which have been found at both sites (Supplemental files 2-3). The main taxa from this category (seabreams, emperors, and groupers) appear to be able to be caught using the same fishing 
498 techniques. These fish can be caught by net, trap, or hook-and-line, and are to be found all year-

499 round, so they may have been used for daily subsistence.

Another environment exploited for fishing by the inhabitants of both sites was the mangrove.

502 Indeed, using the $1 \mathrm{~mm}$ mesh size on both excavations allowed new information to come to

503 light about this specific fishing ground, which is used as a nursery by many species, especially

504 fish (Abu El-Regal and Ibrahim 2014; Laegdsgaard and Johnson 2001; Nagelkerken et al. 2002;

505 Robertson and Duke 1987). The mangrove edges and shores can be considered excellent spots

506 for positioning a fishing camp. These brackish-water ecosystems are normally characterized by

507 their high biomass, with the presence of numerous mullets and sardines (Kulbicki 1997).

508 Although Uerpmann and Uerpmann (2003, 198-199) have already noted the presence of many

509 small fish at Ra's al-Hamra, they minimized their inclusion in the diet of ancient populations by

510 suggesting that they could be tuna stomach contents. Our study, however, places greater

511 importance on these fish as they correspond to an environment highlighted by previous

512 environmental studies showing the most extensive development of mangrove at the end of the

513 fifth millennium/beginning of the fourth millennium BC (Berger et al. 2013; Berger et al. 2005;

514 Biagi and Nisbet 1992; Tengberg 2005). The many hooks found in situ do not coincide with

515 this type of mangrove fishing, however, and the size of the fish suggests the use of small-mesh

516 nets or beach seine. This accords with the small-sized sinkers (Biagi 1999, fig. 14: 1-7), possibly

517 used for cast nets (Marrast 2020; Marrast, Béarez, and Charpentier 2020), or maybe the

518 construction of a fish weir in the mangrove swamp.

\section{Seasonality of fishing activities}

Our results question the seasonality of site occupation. Today, the pelagic species observed in Ra's al-Hamra's faunal assemblage represent an important part of the fishery landings in the 
523 Sultanate of Oman, especially in Muscat. Unfortunately, the data provided by the Ministry of 524 Agriculture and Fisheries (M.A.F. 2013, 2015, 2016, 2018) are not precise enough, with many 525 species (e.g., large jacks, emperors, seabreams) mixed into a single category, which does not 526 allow for a detailed comparison of the data. However, it is clear that some species are caught 527 all year round, while others are available in abundance on a seasonal basis (Figures 6-7).

Figure 6. Compiled data (in metric tons) for 4 years $(2013,2015,2016,2018)$ of artisanal fisheries in Muscat governorate for Thunnus tonggol, Thunnus albacares, Euthynnus affinis, and large jacks (Carangidae) (M.A.F. 2013, 2015, 2016, 2018). The thick line represents the mean. The filled area is the standard deviation of the mean

Figure 7. Ecological distribution of the main taxa found at both sites according to Froese and Pauly (2021), Randall (1995) and personal observations. Vector objects are from Vecteezy.com (Graphics RF)

Jacks and trevallies are regularly caught throughout the year, but this is not the case for tunas and kawakawas (Figure 6A-B, D). In the Muscat landings, kawakawas appear to be continuously caught, but between October and November catches peak (Figure 6C). For longtail tuna, the major peak is between May and June, but abundance is high until October (Figure 6A). Yellowfin tuna is mostly present between September and November (Figure 6B). The occurrence of scombrids in the summer months on the shores of the Gulf of Oman could be linked to the Southwest monsoon (June - September), which brings moist air masses. At the same time, an upwelling phenomenon occurs along the southern coast of Oman, which also affects the Gulf of Oman (Al-Azri et al. 2010; Elliot and Savidge 1990; Watanabe et al. 2017).

547 Upwelling brings nutrient-rich waters to the surface, allowing an important trophic network to 
548 develop, including schools of small pelagics, much sought after by scombrids and other pelagic 549 species (Lee et al. 2000). As for sardines, even if they are available all year round, they are 550 particularly important during the cooler season (Northeast monsoon), between November to 551 March (Al-Jufaili and Al-Jahwari 2011). However, this could be partly due to the fact that 552 weather (strong winds) and sea conditions (big waves) affect the sardine beach seine fishery 553 during the summer. It is likely that coastal communities have been highly dependent on the 554 summer upwelling phenomenon linked to the Southwest monsoon (Biagi and Salvatori 1986; 555 Cavulli and Scaruffi 2013).

As previously mentioned, mangroves are used as a nursery by many species. In this region of the world, seabreams (Acanthopagrus spp. and Rhabdosargus spp.), scads (Trachurus indicus, S. crumenophthalmus), some jacks, trevallies, mojarras (Gerreidae), and goatfishes (Mullidae) spawn in the spring, suggesting that juveniles may be found in the mangrove in summer-autumn. In addition to these juveniles, which are characteristic of this environment, many adult fish are also found in the mangrove: jacks and trevallies, mojarras, and goatfishes all frequent the mangrove in autumn; sardines are spotted between winter and spring; and groupers, parrotfishes, and goatfishes in summer. In general, a peak in mangrove frequentation in this part of the world seems to be marked between winter and spring (Abu El-Regal 2013; Abu El-Regal and Ibrahim 2014; Laroche, Baran, and Rasoanandrasana 1997). Barracudas (Sphyraenidae) and small sharks can also be found throughout the year (Marrast, Béarez, and Charpentier 2020). All studies suggest that juveniles can be found in the mangrove at any time, 
573 with a peak occurrence between spring and summer, suggesting that this was the best time for 574 the exploitation of this marine resource in this ecosystem (Abu El-Regal 2013; Abu El-Regal and Ibrahim 2014; Lidour, Béarez, and Méry 2020; Robertson and Duke 1987).

\section{Seasonality of site occupation}

The exploitation of diverse resources during the 2,000 year occupation at Ra's al-Hamra implies that the communities had an excellent knowledge of the marine coastline, wildlife ecology, and climatic and environmental features (monsoon and upwelling). This fits well with

581 fisher-hunter-gatherer patterns whose subsistence strategies are based on the acquisition of wild 582 resources, implying a long familiarity with biotopes and wildlife ecology (Acheson 1981; Collet 1991). This multifaceted environment allows diversification in the resources consumed, enabling fluctuations in seasonal resources and any possible shortages to be offset (Biagi et al. 1984; Yesner et al. 1980).

Hunter-gatherers vary in their degree of mobility and may occupy different camps throughout the year. According to Yesner et al. (1980), this makes adaptation to resources possible, allowing the exploitation of several ecological niches (Figure 7). However, as hunters do not adapt to a single environment for their subsistence strategy, the long-term use of space can vary over the year. Fishing activities involve the making and handling of fishing gear, as well as fish preparation and storage activities, and require a high degree of social cooperation to manage the capture and arrival of large quantities of fish (Camelin 1995; Collet 1991). Such cooperation, therefore, fits better with a more sedentary lifestyle. 
598 middens indicate winter camps and that Bedouin communities moved onto the piedmont in the

599 primeval period and then into the mountain valleys in small, scattered groups (Cleuziou 2005;

600 Cordes and Scholz 1980; Lancaster and Lancaster 1995). Within archaeological communities,

601 some authors even talk of large-scale transhumance between coastal sites and inland pastures

602 (al-Buhais 18, BHS-18) during the arid periods of the fourth millennium BC (Kutterer and

603 Uerpmann 2017). Even if it is reasonable to consider the idea of small scale nomadism along

604 the wadis between the coast and the foothills, due to the high temperatures recorded on the coast

605 in summer, and because of the perishable character of the habitat structures that suggests

606 structures were temporary (Cavulli and Scaruffi 2013), our data do not confirm such a scenario.

607 This illustrates the complexity surrounding the seasonal occupation of Neolithic sites in the 608 southeast Arabian Peninsula.

609

At RH-5, the community seems to be permanently settled (Munoz 2014; Salvatori 2007),

611 observable in the high density of habitat structures (Marcucci et al. 2011) and no phases of

612 abandonment (Béguier and Marcucci 2018; Marcucci et al. 2011; Marcucci, Badel, and Genchi

613 2021). Moreover, anthropological studies have established a certain genetic isolation (reduced

614 tooth size) and increasing population density, suggesting the sedentary or semi-sedentary

615 lifestyle of the RH-5 inhabitants (Macchiarelli 1989). This hypothesis is reinforced by geochemical analyses on human skeletons, which indicate a strong dependence on marine resources (Zazzo, Munoz, and Saliège 2014; Zazzo et al. 2016). This is consistent with the multi-niche ecological arguments and the slaughter pattern observed in the domestic animals present in the graves. Sometimes the remains indicated more than one and sometimes up to six animals; "such slaughtering events require stable animal populations" (Uerpmann 2003, 79). 
At both sites, our results show that all the fish could have been caught in the vicinity of the

site. The residents of RH-6 and RH-5 intensively exploited pelagic fish, either by hook-andline or by setting nets at a reasonable distance from the coast. However, they also had to supplement this subsistence by setting nets in the mangrove, which provided the opportunity to catch many small fish.

For RH-6, our study is the first to provide results based on such a large corpus of remains, highlighting a predominance of jacks over Thunnini during the entire period of occupation. 631 Fishing activities were mainly oriented toward the exploitation of medium-sized pelagic fish, especially different Thunnini and jacks, which had approximately the same importance. While these pelagic species dominate throughout the occupation, a gradual decrease in pelagic fish is observed over time. occupation of the RH-5 site (3910-3640 cal BC), following the end of the RH-6 occupation.

637 The fishery during phases 1 and 2 mainly exploited small pelagic species, such as sardines or bigeye scads. Their frequency is even greater during phases 3 and 4 , where they constitute more than $90 \%$ of the assemblage. This indicates fishing with small-meshed gillnets or beach seines, as the hooks found at the site are too large to catch such small species.

However, a few medium-sized fish were also present, corresponding mainly to individuals of pelagic species, such as tunas or various jacks. These taxa are easy to catch using hook-andlines thrown from a small boat or even from rocky points, such as those found at the foot of the Ra's al-Hamra cliff. Our study also showed the importance of sieving with a small mesh, which in this case revealed the diversity of the environments exploited and the diversity of fishing techniques implemented at a fishing station in the Neolithic period. These results are extremely 647 promising for redefining the role of fish in the diet and daily life of Neolithic populations. 
648 Indeed, although the importance of marine resources has always been considered by 649 researchers, quantitative and detailed results are still scarce.

In contrast to many contemporary sites in the Persian Gulf (Beech 2004; Lidour, Béarez, and 652 Méry 2020; Lidour and Beech 2019) and in the Arabian Sea, such as SWY-1 and RWY-1 653 (Berger et al. 2020; Marrast, Béarez, and Charpentier 2020) where lagoons have been mainly 654 exploited, the Neolithic inhabitants of the capital area of Muscat appear to have specialized in 655 the exploitation of coastal pelagic species. This kind of exploitation has already been 656 highlighted at a few sites in the Persian Gulf, particularly at Akab, where carangids and scombrids represented $50 \%$ of the material (Lidour et al. 2020), and at Khor Milkh 1 (KM-1) (Uerpmann and Uerpmann 2003, 194), just south of Ra's al-Hamra. However, the specialization of this type of fishing (more than $80 \%$ at RH-6 and RH-5) in the Gulf of Oman is, for the moment, unique in this region. New ichthyoarchaeological studies in the region and their 661 publication, especially from more recent sites (Bronze Age) or from areas that are still poorly 662 known, will make it possible to complete the picture of ancient fisheries in this part of the world and, in particular, to better understand the reasons that led the coastal inhabitants to turn to populations of southeast Arabia.

\section{SUPPLEMENTAL FILES}

Supplemental file 1. List and NISP of taxa recovered at RH-6 and RH-5, arranged in

671 taxonomic order. B: benthic; D: demersal; EP: epipelagic; P: pelagic. For fish behaviour, we 

possible fishing environment. Pelagic fishes: (A) Thunnus albacares, precaudal vertebra (ventral view); (B) Thunnus tonggol, caudal vertebra (lateral view); (C) Euthynnus affinis, precaudal vertebra (ventral view); (D) Caranx sexfasciatus, right cleithrum (lateral view); (E)

Carangoides chrysophyrs, supraoccipital hyperostosis (lateral view); (F) Gnathanodon speciosus, precaudal vertebra (ventral view). Demersal fishes: (G) Sufflamen fraenatum, left

Supplemental file 3. Illustration of different bones from main taxa at both sites and possible fishing environment. Small pelagic fishes: (A) Selar crumenophthalmus, precaudal vertebra (ventral view); (B) Clupeidae (cf. Sardinella longiceps), precaudal vertebra (ventral view); (C) Alepes djedaba, first vertebra (ventral view); (D) Rastrelliger kanagurta, caudal vertebra (lateral view); (E) Mugilidae, precaudal vertebra (ventral view). Juvenile demersal fishes: (F) Pomadasys sp., first vertebra (ventral view); (G) Sparoidea, teeth; (H-I) Qurum mangrove views

\section{ACKNOWLEDGEMENTS}

697 Thanks are also due to K. Debue and B. David for assistance with the sorting of the $1 \mathrm{~mm}$ sieved 
698 sediments, to A. Coppa for the funding of the date of sector B2 of RH 5, to A. Zazzo and M.

699 Tengberg for their advice, to H. David for the use of her map of the sites of Ra's al-Hamra, and 700 to J. Cucchi for copy editing. We would also like to thank the reviewers and the editor for their 701 contributions to our manuscript. Finally, the authors address their posthumous thanks to M. 702 Tosi who worked for a long time on the sites of Ra's al-Hamra and did much for the archaeology 703 of this area and the Sultanate.

706 The authors declare that they have no conflict of interest. 
709

710

711

712

713

714

715

716

717

718

719

720

721

722

723

724

725

726

727

728

729

730

731

732

733

734

735

736

737

738

Abu El-Regal, M. 2013. Spawning seasons, spawning grounds and nursery grounds of some Red Sea fishes. The Global Journal of Fisheries and Aqua 6(6): 105-125.

Abu El-Regal, M., and N. K. Ibrahim. 2014. Role of mangroves as a nursery ground for juvenile reef fishes in the southern Egyptian Red Sea. Egyptian Journal of Aquatic Research 40: 71-78. doi:10.1016/j.ejar.2014.01.001.

Acheson, J. M. 1981. Anthropology of fishing. Annual Review of Anthropology 10: 275-316. doi:10.1146/annurev.an.10.100181.001423.

Al-Azri, A. R., S. A. Piontkovski, K. A. Al-Hashmi, J. I. Goes, and H. R. do Gomes. 2010. Chlorophyll a as a measure of seasonal coupling between phytoplankton and the monsoon periods in the Gulf of Oman. Aquatic Ecology 44(2): 449-461.

Al-Azri, A. R., S. A. Piontkovski, K. A. Al-Hashmi, J. I. Goes, H. R. do Gomes, and P. M. Glibert. 2014. Mesoscale and nutrient conditions associated with the massive 2008 Cochlodinium polykrikoides bloom in the Sea of Oman/Arabian Gulf. Estuaries and Coasts 37 (2): 325-338. doi:10.1007/s12237-013-9693-1.

Al-Jufaili, S. M., and O. S. Al-Jahwari. 2011. The Omani coastal traditional sardine fishery 1994-2007: A review. Agricultural and Marine Sciences 16: 1-12.

Al-Marshudi, A. S., and H. Kotamaga. 2006. Socio-economic structure and performance of traditional fishermen in the Sultanate of Oman. Marine Resource Economics 21 (2): 221-230. doi:10.1086/mre.21.2.42629506.

Anderson, A. 2013. The Antiquity of sustained offshore fishing. Antiquity 87 (337): 879-885. doi:10.1017/S0003598X00049541.

Béarez, P., F. Fuentes-Mucherl, S. Rebolledo, D. Salazar, and L. Olguín. 2016. Billfish foraging along the northern coast of Chile during the Middle Holocene (7400-5900cal BP). Journal of Anthropological Archaeology 41: 185-195. doi:10.1016/j.jaa.2016.01.002.

Béarez, P., P. Gay, and R. Lunniss. 2012. Sea fishing at Salango (Manabí Province, Ecuador) during the Middle Formative Machalilla phase. Latin American Antiquity 23 (2): 195214.

Beech, M. J. 2004. In the land of the Ichthyophagi: Modelling fish exploitation in the Arabian Gulf and Gulf of Oman from the 5th millennium BC to the Late Islamic period. BAR International Series 1217. Oxford: Archaeopress.

Beech, M. J., K. Strutt, L. Blue, A. K. Al-Kaabi, W. A. Omar, A. A. A. H. El-Faki, A. R. Lingareddy, and J. Martin. 2016. Ubaid-related sites of the southern Gulf revisited: The Abu Dhabi coastal heritage initiative. Proceedings of the Seminar for Arabian Studies 46: 9-23. doi:10.2307/45163414.

Béguier, I., and L. G. Marcucci. 2018. Première approche micromorphologique de la fin de l'occupation néolithique d'un amas coquillier de la côte omanaise: données préliminaires sur les modes d'occupation du site de RH-5 dans la seconde moitié du 4e millénaire BCE [Initial micromorphological approach of the Neolithic occupation of a shell midden on the Omani coastline: Preliminary data on the occupation patterns of the RH-5 site in the second half of the 4th millennium]. ArcheoSciences 42 (2): 7-30. doi:10.4000/archeosciences.5667.

Berger, J.-F., V. Charpentier, R. Crassard, C. Martin, G. Davtian, and J. A. López-Sáez. 2013. The dynamics of mangrove ecosystems, changes in sea level and the strategies of neolithic settlements along the coast of Oman (6000-3000 Cal. BC). Journal of Archaeological Science 40 (7): 3087-3104. doi:10.1016/j.jas.2013.03.004.

Berger, J.-F., S. Cleuziou, G. Davtian, M. Cattani, F. Cavulli, V. Charpentier, M. Cremaschi, J. Giraud, P. Marquis, C. Martin, et al. 2005. Evolution paléogéographique du Ja'alan (Oman) à l'Holocène moyen: Impact sur l'évolution des paléomilieux littoraux et les 
stratégies d'adaptation des communautés humaines [Paleogeographic evolution of Ja'alan (Oman) in the Middle Holocene: Impact on the evolution of coastal paleoenvironments and on the adaptative strategies of human communities]. Paléorient 31 (1): 46-63.

Berger, J.-F., R. Guilbert-Berger, A. Marrast, O. Munoz, H. Guy, A. Barra, J. A. López-Sáez, S. Pérez-Díaz, M. Mashkour, K. Debue et al. 2020. First contribution of the excavation and chronostratigraphic study of the Ruways 1 Neolithic shell midden (Oman) in terms of neolithisation, palaeoeconomy, social-environmental interactions and site formation processes. Arabian Archaeology and Epigraphy 31 (1): 32-49. doi:10.1111/aae.12144. Biagi, P. 1987. The prehistoric fishermen settlements of RH5 and RH6 at Qurum, Sultanate of Oman. Proceedings of the Seminar for Arabian Studies 17: 15-19. doi: $10.2307 / 41223038$.

Biagi, P. 1994. A radiocarbon chronology for the aceramic shell-middens of coastal Oman. Arabian Archaeology and Epigraphy 5: 17-31. doi:10.1111/j.16000471.1994.tb00053.x.

Biagi, P. 1999. Excavations at the shell-midden of RH6 1986-1988 (Muscat, Sultanate of Oman). Al-Rāfidān 20: 57-84.

Biagi, P. 2006. The shell-middens of the Arabian Sea and Gulf: Maritime connections in the seventh millennium BP? In The city in the arab world in light of archaeological discoveries: Evolution and development, ed. A. R. Al-Ansary, K. I. Al-Muaikel, and A. M. Alsharekh, 7-18. Al-Jouf: Abdul Rahman Al-sudairy Foundation.

Biagi, P, and R. Maggi. 1987. Archaeological surveys along the Oman coast: Preliminary results of five years of research (1983-1987). South Asian Archaeology 1: 1990.

Biagi, P., and R. Nisbet. 1992. Environmental history and plant exploitation at the aceramic sites of RH5 and RH6 near the mangrove swamp of Qurm (Muscat-Oman). Bulletin de La Société Botanique de France. Actualités Botaniques 139 (2-4): 571-578. doi:10.1080/01811789.1992.10827129.

Biagi, P., and R. Nisbet. 1999. The shell-midden sites of RH-5 and RH-6 (Muscat, Sultanate of Oman) in their environmental setting. Archaeologia Polona 37: 31-47.

Biagi, P., and R. Nisbet. 2006. The prehistoric fisher-gatherers of the western coast of the Arabian Sea: A case of seasonal sedentarization? World Archaeology 38 (2): 220-238. doi: $10.1080 / 00438240600708188$.

Biagi, P., S. Salvatori. 1986. Gli scavi nell'insediamento preistorico e nella necropoli di Ra's al-Hamra 5 (Muscat, Oman), 1980-1985. Rivista di Archeologia 10: 5-14.

Biagi, P., W. Torke, M. Tosi, and H.-P. Uerpmann. 1984. Qurum: A case study of coastal archaeology in northern Oman. World Archaeology 16 (1): 43-61. doi: $10.1080 / 00438243.1984 .9979915$.

Biagi, P., and R. A. Travers. 1985. Non-mammalian osteological remains and fishing implements at RH-5 and RH-6, Muscat. East and West 35 (4): 407-410.

Camelin, S. 1995. Les pêcheurs de Shihr. Transmission du savoir et identité sociale. Arabian Humanities. 3. doi:10.4000/cy.80.

Carter, R. A., and H. E. W Crawford. 2010. Maritime interactions in the Arabian Neolithic: The evidence from H3, As-Sabiyah, an Ubaid-related site in Kuwait. Leiden: Brill.

Cartwright, C. R. 2004. Reconstructing the use of coastal resources at Ra's Al-Hadd, Oman, in the Third Millennium BC. Proceedings of the Seminar for Arabian Studies 34: 45-51.

Cavulli, F., and S. Scaruffi. 2013. Thoughts on nomadism in Middle Holocene Oman. Arabian Archaeology and Epigraphy 24: 15-27. doi:10.1111/aae.12023.

Charpentier, V. 2008. Hunter-gatherers of the 'Empty Quarter of the Early Holocene' to the Last Neolithic societies: Chronology of the Late Prehistory of south-eastern Arabia (8000-3100 BC). Proceedings of the Seminar for Arabian Studies 38: 93-115. 
Charpentier, V., J.-F. Berger, R. Crassard, F. Borgi, G. Davtian, S. Méry, and C. S. Phillips. 2013. Conquering new territories: When the first black boats sailed to Masirah Island. Proceedings of the Seminar for Arabian Studies 43: 85-98.

Chenorkian, R. 1996. Pratique archéologique statistique et graphique. Méthodes et techniques. Paris: Ed. Errance, Lattes: Association pour la diffusion de l'archéologie méridionale.

Cleuziou, S. 2003. Early Bronze Age trade in the Gulf and the Arabian Sea: The Society behind the Boats. In Archaeology of the United Arab Emirates, edited by Daniel T. Potts, Hasan Al Naboodah, and Peter Hellyer, 133-150. Abu Dhabi, 2001: Trident Press Ltd.

Cleuziou, S. 2005. Pourquoi si tard? Nous avons pris un autre chemin. L'Arabie des chasseurscueilleurs de l'Holocène au début de l'Age du Bronze [Why so late? We have taken a different route. The Arabia of the hunter-gatherers from the Holocene to the Early Bronze Age]. In Aux marges des grands foyers du Néolithique. Périphéries débitrices ou créatrices ?, ed. J. Guilaine, 123-148. Collection des Hespérides. Paris: Editions Errance.

Cleuziou, S., and M. Tosi. 2007. In the shadow of the ancestors. The prehistoric foundations of the early Arabian civilization in Oman. Muscat: Ministry of Heritage \& Culture, Sultanat of Oman.

Collet, S. 1991. Guerre et pêche : quelle place pour les sociétés de pêcheurs dans le modèle des chasseurs-cueilleurs? [War and fishing: What place for fishing societies in the huntergatherer model?]. Social Science Information 30 (3): 483-522.

Collette, B. B. 2001. Scombridae. Tunas (Also, albacore, bonitos, mackerels, seerfishes, and wahoo). FAO species identification guide for fishery purposes. The living marine resources of the Western Central Pacific 6: 3721-3756.

Collette, B. B., and C. E. Nauen. 1983. Scombrids of the world. An annotated and illustrated catalogue of tunas, mackerels, bonitos and related species known to date. Vol. 2. FAO Species Catalogue. Rome: Food \& Agriculture Organization of the United Nations. http://www.fao.org/docrep/009/ac478e/ac478e00.htm.

Coppa, A., R. Macchiarelli, S. Salvatori, and G. Santini. 1985. The prehistoric graveyard of Ra's al-Hamra (RH 5). Journal of Oman Studies, 8(1): 97-102.

Cordes, R., and F. Scholz. 1980. Bedouins, wealth, and change. A study of rural development in the United Arab Emirates and the Sultanate of Oman. Tokyo: The United Nations University. https://www.cabdirect.org/cabdirect/abstract/19811875308.

Durante, S., and M. Tosi. 1977. The aceramic shell middens of Ra's al-Hamra: A preliminary note. The Journal of Oman Studies 3 (2): 137-162.

Elliott, A. J., and G. Savidge. 1990. Some features of the upwelling off Oman. Journal of Marine Research 48 (2): 319-333.

Fleitmann, D., S. J. Burns, A. Mangini, M. Mudelsee, J. Kramers, I. Villa, U. Neff, A. A. AlSubbary, A. Buettner, D. Hippler, et al. 2007. Holocene ITCZ and Indian monsoon dynamics recorded in stalagmites from Oman and Yemen (Socotra). Quaternary Science Reviews 26 (1): 170-188. doi:10.1016/j.quascirev.2006.04.012.

Frazier, J. G., V. Azzarà, O. Munoz, L. G. Marcucci, É. Badel, F. Genchi, M. Cattani, M. Tosi, and M. Delfino. 2018. Remains of leatherback turtles, Dermochelys coriacea, at MidLate Holocene archaeological sites in coastal Oman: Clues of Past Worlds. PeerJ 6: 134. doi: $10.7717 /$ peerj. 6123.

Fricke, R., W. N. Eschmeyer, and R. Van der Laan, eds. 2021. Eschmeyer's Catalog of Fishes: Genera, Species, References. Electronic version accessed 8 June 2021. http://researcharchive.calacademy.org/research/ichthyology/catalog/fishcatmain.asp.

Froese, R., and D. Pauly, eds. 2021. FishBase. World Wide Web electronic publication. www.fishbase.org 
Goddard, D. 1985. Exeter maritime museum. The Mariner's Mirror 71 (2). Routledge: 201214. doi:10.1080/00253359.1985.10656025.

Grandcourt, E. M. 2012. Reef fish and fisheries in the Gulf. In Coral Reefs of the Gulf: Adaptation to Climatic Extremes, edited by Bernhard M. Riegl and Sam J. Purkis, 127161. Coral Reefs of the World 3. Dordrecht: Springer Netherlands. doi:10.1007/978-94007-3008-3_8.

Grandcourt, E. M., T. Z. Al Abdessalaam, F. Francis, and A. T. Al Shamsi. 2004. Biology and stock assessment of the sparids, Acanthopagrus bifasciatus and Argyrops spinifer (Forsskål, 1775), in the southern Arabian Gulf. Fisheries Research 69 (1): 7-20.

Johnson, D. V. 2016. Unusual date palm products: Prayer beads, walking sticks and fishing boats. Emirates Journal of Food and Agriculture 28 (1): 12-16. doi:10.9755/ejfa.201511-1021.

Karachle, P. K., D. Dimarchopoulou, A. C. Tsikliras. 2020. Is shore-based recreational fishing in Greece an unregulated activity that increases catch uncertainty? Regional Studies in Marine Science 36: 101273

Kulbicki, M. 1997. Bilan de 10 ans de recherche (1985-1995) par l'ORSTOM sur la diversité, la densité, la biomasse et la structure trophique des communautés des poissons lagonaires et récifaux en Nouvelle-Calédonie [Results of ten years of research (19851995) by ORSTOM on diversity, density, biomass, and community trophic structure of the lagoon and reef fishes in New Caledonia]. Cybium 21 (1): 47-79.

Laegdsgaard, P., and C. Johnson. 2001. Why do juvenile fish utilise mangrove habitats? Journal of Experimental Marine Biology and Ecology 257 (2): 229-253. doi:10.1016/S00220981(00)00331-2.

Lancaster, W., and F. Lancaster. 1995. Nomadic fishermen of Ja'alân, Oman. Nomadic Peoples 36/37: 227-243.

Laroche, J., E. Baran, and N. B. Rasoanandrasana. 1997. Temporal patterns in a fish assemblage of a semiarid mangrove zone in Madagascar. Journal of Fish Biology 51 (1): 3-20. doi:10.1111/j.1095-8649.1997.tb02509.x.

Lee, C. M., B. H. Jones, K. H. Brink, and A. S. Fischer. 2000. The upper-ocean response to monsoonal forcing in the Arabian Sea: Seasonal and spatial variability. Deep-Sea Research Part II: Tropical Studies in Oceanography 47 (7-8): 1177-1226. doi:10.1016/S0967-0645(99)00141-1.

Lézine, A.-M., S. J. Ivory, P. Braconnot, and O. Marti. 2017. Timing of the southward retreat of the ITCZ at the end of the Holocene humid period in southern Arabia: Data-model comparison. Quaternary Science Reviews 164: 68-76. doi:10.1016/j.quascirev.2017.03.019.

Lidour, K., P. Béarez, V. Charpentier, and S. Méry. 2020. The prehistoric fisheries of Akab Island (United Arab Emirates): New insights into coastal subsistence during Neolithic in eastern Arabia. The Journal of Island and Coastal Archaeology 15 (1): 80-103. doi:10.1080/15564894.2018.1531330.

Lidour, K., P. Béarez, and S. Méry. 2020. Analysis of archaeological fish remains provides new insights into seasonal mobility in eastern Arabia during the Mid-Holocene. The subsistence fisheries of UAQ36, Umm al-Quwain lagoon (United Arab Emirates). Journal of Archaeological Science: Reports 30: 102223. doi:10.1016/j.jasrep.2020.102223.

Lidour, K., and M. J. Beech. 2019. The numerous islands of Ichthyophagi': Neolithic fisheries of Delma Island, Abu Dhabi Emirate (UAE). Proceedings of the Seminar for Arabian Studies 49: 207-222.

Macchiarelli, R. 1989. Prehistoric 'fish-eaters' along the eastern Arabian coasts: Dental variation, morphology, and oral health in the Ra's al-Hamra community (Qurum, 
Sultanate of Oman, 5th-4th Millennia BC). American Journal of Physical Anthropology 78 (4): 575-594. doi:10.1002/ajpa.1330780411.

M.A.F. (Ministry of Agriculture and Fisheries). 2013. Fisheries statistics book. Mascate: Ministry of Agriculture and Fisheries - General directorate of Planning and Development Fisheries Statistic Department.

M.A.F. (Ministry of Agriculture and Fisheries). 2015. Fisheries statistics book. Mascate: Ministry of Agriculture and Fisheries - General directorate of Planning and Development Fisheries Statistic Department.

M.A.F. (Ministry of Agriculture and Fisheries). 2016. Fisheries statistics book. Mascate: Ministry of Agriculture and Fisheries - General directorate of Planning and Development Fisheries Statistic Department.

M.A.F. (Ministry of Agriculture and Fisheries). 2018. Fisheries statistics book. Mascate: Ministry of Agriculture and Fisheries - General directorate of Planning and Development Fisheries Statistic Department.

Marcucci, L. G. 2015. I siti preistorici di RH-5 e RH-6 a Ra's al-Hamra (Muscat, Sultanato d'Oman): analisi comparativa della stratigrafia, delle strutture di abitato e della cultura materiale. Continuità e sviluppo di due villaggi di pescatori-raccoglitori [The prehistoric sites of RH-5 and RH-6 at Ra's al-Hamra (Muscat, Sultanate of Oman): Comparative analysis of the stratigraphy, the living structures and the material culture. Continuity and development of two villages of fisher-gatherers]. $\mathrm{PhD}$ diss., Université Paris 1 Panthéon-Sorbonne, Università di Bologna.

Marcucci, L. G., É. Badel, and F. Genchi. 2021. Prehistoric fisherfolk of Oman: The Neolithic village of Ras Al-Hamra RH-5. The Archaeological heritage of Oman, Vol. 6. Oxford: Archaeopress.

Marcucci, L. G., É. Badel, F. Genchi, O. Munoz, A. Todero, and M. Tosi. 2014. New investigations at the prehistoric shell midden of Ra's al-Hamra 6 (Sultanate of Oman): Results of the 2012 and 2013 Excavation Seasons. Proceeding for Arabian Studies 44: 235-256.

Marcucci, L. G., F. Genchi, É. Badel, and M. Tosi. 2011. Recent investigations at the prehistoric site RH-5 (Ra's al-Hamra, Muscat, Sultanate of Oman). Proceeding for Arabian Studies. 41: 201-222.

Marrast, A. 2020. Stratégies d'exploitation des environnements côtiers arides: les activités halieutiques du Néolithique à l'âge du Bronze dans le Sud Est de la péninsule arabique (Sultanat d'Oman) [Exploitation strategies in arid coastal environments: Fishing activities from the Neolithic to the Bronze Age in the south-eastern Arabian Peninsula (Sultanate of Oman)]. PhD diss., Muséum national d'histoire naturelle.

Marrast, A., P. Béarez, and V. Charpentier. 2020. Sharks in the lagoon? Fishing exploitation at the neolithic site of Suwayh 1 (Ash Sharqiyah Region, Arabian Sea, Sultanate of Oman). Arabian Archaeology and Epigraphy 31 (1): 178-193. doi:10.1111/aae.12136.

McClure, H. A. 1976. Radiocarbon chronology of Late Quaternary lakes in the Arabian desert. Nature 263 (5580): 755-756. doi:10.1038/263755a0.

Miles, S. B. 1910. On the border of the great desert: A journey in Oman. Geographical Journal 36 (2): $159-178$.

Munoz, O. 2014. Pratiques funéraires et paramètres biologiques dans la péninsule d'Oman du Néolithique à la fin de l'âge du Bronze ancien (Ve-IIIe millénaires av. NE) [Funerary practices and biological parameters in the Oman Peninsula from the Neolithic to the end of the Early Bronze Age (5th-3rd mill. BCE)]. PhD diss., Université Paris 1 PanthéonSorbonne. http://www.theses.fr/2014PA010514.

Nagelkerken, I., C. M. Roberts, G. Van der Velde, M. Dorenbosch, M. C. Van Riel, E. Cocheret De La Moriniere, and P. H. Nienhuis. 2002. How important are mangroves and seagrass 
beds for coral-reef fish? The nursery hypothesis tested on an island scale. Marine Ecology Progress Series 244: 299-305.

Nourissier, A., N. Nocus, and A. Dufraisse. 2016. ACACIA: Automatical Creation of Anthracological Diagram. The User Guide. Available on https://dendrac.mnhn.fr/spip.php?rubrique69

Pickard, C., and C. Bonsall. 2004. Deep-sea fishing in the European Mesolithic: Fact or fantasy? European Journal of Archaeology 7 (3). Routledge: 273-290. doi:10.1177/1461957104056504.

Poplin, F. 1976. A propos du nombre de restes et du nombre d'individus dans les échantillons d'ossements [About the number of remains and the number of individuals in bone samples]. Cahiers du Centre de recherches préhistoriques 5: 61-75.

Randall, J. E. 1995. Coastal fishes of Oman. University of Hawaii Press.

Richardson N. and M. Dorr. 2003. The craft heritage of Oman. Dubai: Motivate Publishing.

Robertson, A. I., and N. C. Duke. 1987. Mangroves as nursery sites: Comparisons of the abundance and species composition of fish and crustaceans in mangroves and other nearshore habitats in tropical Australia. Marine Biology 96 (2): 193-205. doi:10.1007/BF00427019.

Salvatori, S. 2007. The prehistoric graveyard of Ra's Al Hamrā 5, Muscat, Sultanate of Oman. Mascate: Ministry of Heritage and Culture, Sultanate of Oman.

Strømme, T. 1986. The pelagic and demersal fish resources of Oman. Results of the R/V Dr. Fridtjof Nansen surveys in Oman 1983-84. Final report from surveys 1983-84. Bergen: Institute of Marine Research. http://agris.fao.org/agrissearch/search.do?recordID=XF2016072613.

Tengberg, M. 2005. Les forêts de la mer. Exploitation et évolution des mangroves en Arabie orientale du Néolithique à l'époque islamique [The forests of the sea. Exploitation and evolution of mangroves in Eastern Arabia from the Neolithic to the Islamic period]. Paléorient 31 (1): 39-45.

Thomas R., M. Tengberg, C. Moulhérat, V. Marcon and R. Besenval. 2012. Analysis of a protohistoric net from Shahi Tump, Baluchistan (Pakistan). Archaeological and Anthropological Sciences 4: 15-23. doi: 10.1007/s12520-011-0078-8

Tosi, M. 1975. Notes on the distribution and exploitation of natural resources in ancient Oman. Journal of Oman Studies 1: 187-206.

Uerpmann, H.-P., and M. Uerpmann. 2003. The capital area of northern Oman. Part III, Stone Age sites and their natural environment. Wiesbaden: Dr. Ludwig Reicherd Verlag.

Uerpmann, M. 2003. The Dark Millennium: Remarks on the Final Stone Age in the Emirates and Oman. In Archaeology of the United Arab Emirates, ed. D. T. Potts, H. Al Naboodah, and P. Hellyer, 74-81. Abu Dhabi: Trident Press Limited.

Uerpmann M. and H.-P. Uerpmann, 2018. Chapter 20. Faunal remains and subsistence strategies. In Dosariyah: Reinvestigating a Neolithic coastal community in eastern Arabia. Ed. P. Drechsler: 384-422. British Foundation for the Study of Arabia Monographs 19. Oxford: Archaeopress.

Vita-Finzi, C. 1982. Recent coastal deformation near the Strait of Hormuz. Proceedings of the Royal Society A: Mathematical, Physical and Engineering Sciences 382 (1783): 441457.

von den Driesch, A., and H. Manhart, 2000. Fish bones from Al Markh, Bahrain. In Archaeozoology of the Near East IVB. Proceedings of the fourth international symposium on the archaeozoology of southwestern Asia and adjacent areas. Eds. M. Mashkour, A. M., Choyke, H., Buitenhuis, and F. Poplin: 350-367. Groningen: ARC Publicatie. 
Vosmer, T. 2019. Sewn boats in Oman and the Indian Ocean. International Journal of Nautical Archaeology 48 (2): 302-313. doi:10.1111/1095-9270.12371.

Watanabe, T. K., T. Watanabe, A. Yamazaki, M. Pfeiffer, D. Garbe-Schönberg, and M. R. Claereboudt. 2017. Past summer upwelling events in the Gulf of Oman derived from a coral geochemical record. Scientific Reports 7(1). doi:10.1038/s41598-017-04865-5

Wheeler, A., and A. K. G. Jones. 1989. Fishes. Cambridge, New York: Cambridge University Press.

Wilkens, B. 2005. Fishing in the Arabian Sea: A short note on the prehistoric sites RH6 and Ra's al-Jinz 1 in Oman. Paléorient 31 (1): 126-130.

Yesner, D. R., W. S. Ayres, D. L. Carlson, R. S. Davis, R. Dewar, M. R. González Morales, F. A. Hassan, B. Hayden, J. J. Lischka, P. D. Sheets, et al. 1980. Maritime huntergatherers: Ecology and prehistory [and Comments and Reply]. Current Anthropology 21 (6): 727-750. doi:10.1086/202568.

Zazzo, A., O. Munoz, É. Badel, I. Béguier, F. Genchi, and L. G. Marcucci. 2016. A revised radiocarbon chronology of the aceramic shell midden of Ra's Al-Hamra 6 (Muscat, Sultanate of Oman): Implication for occupational sequence, marine reservoir age, and human mobility. Radiocarbon 58 (2): 383-395. doi:10.1017/RDC.2016.3.

Zazzo, A., O. Munoz, and J.-F. Saliège. 2014. Diet and mobility in a Late Neolithic population of coastal Oman inferred from radiocarbon dating and stable isotope analysis. American Journal of Physical Anthropology 153 (3): 353-364. doi:10.1002/ajpa.22434. 


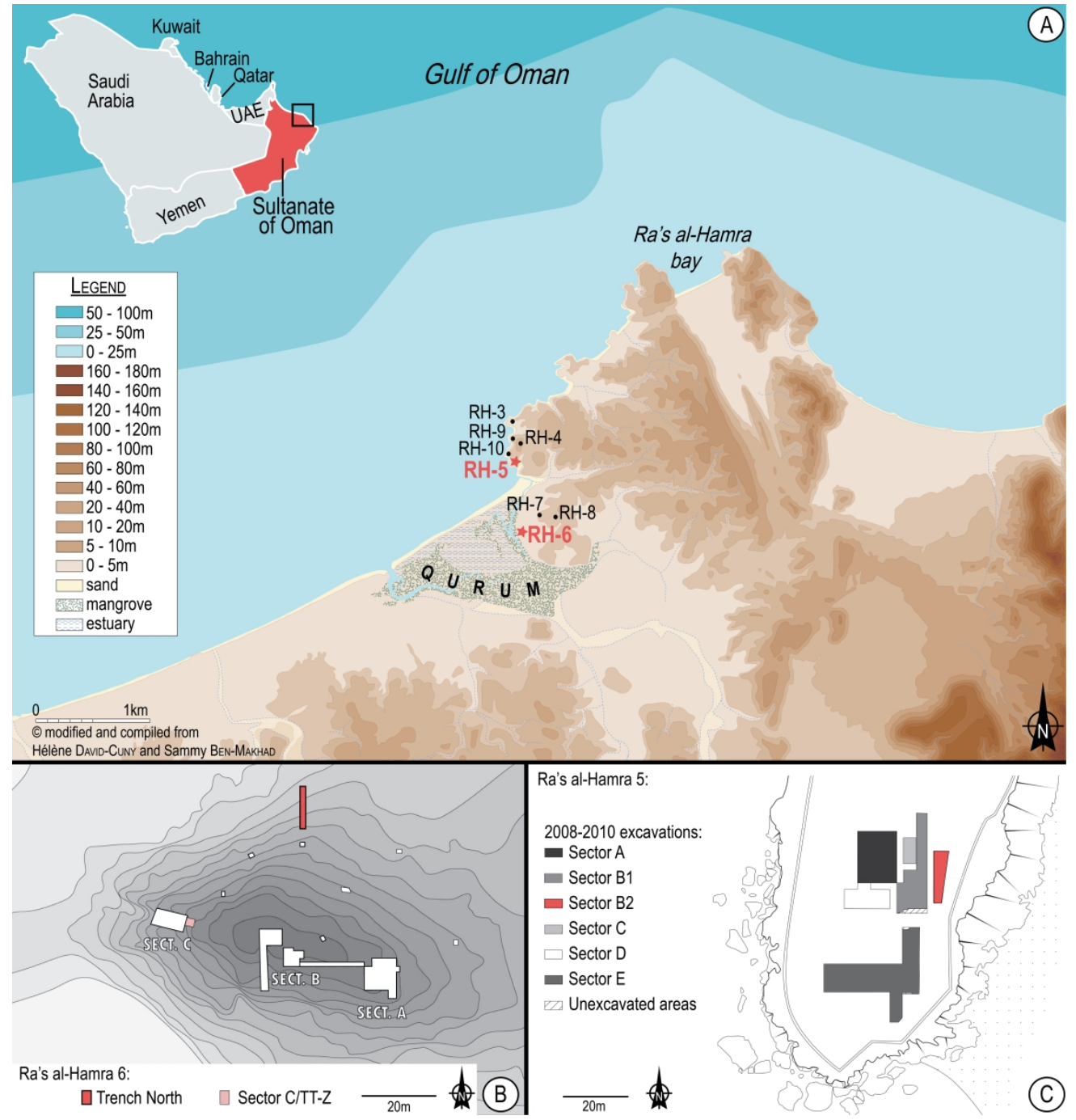

Figure 1. (A) Location, altitudinal and bathymetric mapping of the Qurum mangrove and the Ra's al-Hamra's cape, with location of the archaeological sites; (B) Map of the excavated sectors of RH-6 (Marcucci et al., 2014, fig. 1.A.); and (C) Map of the excavated sectors of RH-5 (Marcucci et al., 2011, fig. 2.) 


\begin{tabular}{|c|c|c|c|c|c|c|c|c|c|c|}
\hline \multirow{2}{*}{ Main taxa } & \multicolumn{2}{|c|}{$\begin{array}{l}\text { RH-6 } \\
\text { (Uerpmann } \\
\text { and } \\
\text { Uernmann }\end{array}$} & \multicolumn{2}{|c|}{$\begin{array}{c}\text { RH-6 } \\
\text { (Wilkens } \\
\text { 2005) } \\
\end{array}$} & \multicolumn{3}{|c|}{$\begin{array}{c}\mathrm{RH}-5 \\
\text { (Uerpmann and Uerpmann } \\
\text { 2003) }\end{array}$} & \multicolumn{3}{|c|}{ M.A.F. (2018) } \\
\hline & NISP & WISP & NISF & WISP & NISP & NISP \% & WISP & Catches (tons) & $\%$ & $\begin{array}{c}\% \\
\text { (without small } \\
\text { pelagic) }\end{array}$ \\
\hline Scombridae & 23 & 9.1 & 311 & - & 7596 & 58.9 & 6527.4 & 49466 & 28.1 & 44.0 \\
\hline Carangidae & 22 & 15.8 & 74 & - & 4065 & 31.5 & 5934.7 & 10572 & 6.0 & 9.4 \\
\hline Other pelagic fish & 2 & 0.1 & 17 & - & 209 & 1.6 & 100.5 & 18203 & 10.3 & 16.2 \\
\hline Mugilidae & 1 & 0.2 & 3 & - & 11 & 0.1 & 5.3 & 821 & 0.5 & \\
\hline Small pelagic fish & - & - & - & - & - & - & - & 62897 & 35.7 & \\
\hline Sparidae & 2 & 0.1 & 47 & - & 662 & 5.1 & 295.4 & 2533 & 1.4 & 2.3 \\
\hline Lethrinidae & - & - & 19 & - & 150 & 1.2 & 117.4 & 5356 & 3.0 & 4.8 \\
\hline Serranidae & - & - & 56 & - & 36 & 0.3 & 76.6 & 3359 & 1.9 & 3.0 \\
\hline Other demersal fish & $1^{*}$ & 0.3 & 36 & - & 150 & 1.2 & 171.8 & 15243 & 8.6 & 13.5 \\
\hline Sharks/Rays & - & - & 7 & - & 12 & 0.1 & 20.2 & 7777 & 4.4 & 6.9 \\
\hline Total NISP & 51 & 25.6 & 570 & 0 & 12891 & 100 & 13249.3 & 176227 & 100 & 100 \\
\hline
\end{tabular}

Table 1. Table synthetizing the main results from previous studies on the fish bone remains from $\mathrm{RH}-6$ and $\mathrm{RH}-5$

(for Uerpmann and Uerpmann 2003, NISP have been calculated from identified Actinopterygii and Chondrichthyes), and modern data of artise fishing from the governorate of Muscat for 2009-2018 (M.A.F. 2018). *Ariidae 


\begin{tabular}{|c|c|c|c|c|c|}
\hline \multirow{2}{*}{\multicolumn{2}{|c|}{ Anatomical element }} & \multicolumn{3}{|c|}{ Total RH-6 } & \multirow[b]{2}{*}{ Total RH-5 } \\
\hline & & \multirow{3}{*}{$\begin{array}{c}\begin{array}{c}\text { Trench North } \\
(3 \mathrm{~mm})\end{array} \\
528 \\
353\end{array}$} & \multirow{2}{*}{\begin{tabular}{|c|}
$\begin{array}{c}\text { Sector C/TT-Z } \\
(3 \mathrm{~mm})\end{array}$ \\
496
\end{tabular}} & $\begin{array}{c}\text { Sector C/TT-Z } \\
(1 \mathrm{~mm}) \\
\end{array}$ & \\
\hline \multirow{16}{*}{ 志 } & Dentary & & & 6 & 23 \\
\hline & Premaxilla & & 508 & 10 & 31 \\
\hline & Maxilla & 248 & 206 & 1 & 5 \\
\hline & Quadrate & 179 & 263 & 4 & 12 \\
\hline & Opercle & 187 & 209 & 6 & 7 \\
\hline & Anguloarticular & 166 & 209 & 1 & 4 \\
\hline & Cleithrum & 232 & 114 & - & 7 \\
\hline & Vomer & 133 & 113 & 2 & 2 \\
\hline & Scapula & 26 & 100 & 1 & 4 \\
\hline & Pharyngeal bone & 49 & 63 & - & 1 \\
\hline & Tooth & 41 & 50 & 406 & 215 \\
\hline & Hyomandibula & 19 & 61 & 1 & 1 \\
\hline & Palatine & 17 & 31 & - & 4 \\
\hline & $\begin{array}{l}\text { Basioccipital/ } \\
\text { Parasphenoid }\end{array}$ & 66 & 50 & 13 & 50 \\
\hline & Otolith & - & 1 & 21 & 2 \\
\hline & Other & 248 & 289 & - & 44 \\
\hline \multirow{4}{*}{ 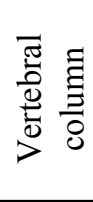 } & First vertebra & 284 & 127 & 707 & 1417 \\
\hline & Precaudal vertebra & 2069 & 2103 & 4065 & 4349 \\
\hline & Caudal vertebra & 3211 & 3242 & 5257 & 2926 \\
\hline & Other & 712 & 231 & 1 & 14 \\
\hline \multirow{3}{*}{$\frac{n}{\stackrel{0}{0}}$} & Pterygiophore & 493 & 704 & 17 & 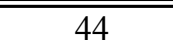 \\
\hline & Scale & - & - & 41 & - \\
\hline & Scute & 188 & 1 & - & 4 \\
\hline \multirow{3}{*}{$\begin{array}{l}\dot{\vec{t}} \\
\dot{0} \\
\dot{0}\end{array}$} & Tooth & 2 & - & 2 & 2 \\
\hline & Vertebra & 4 & 3 & - & - \\
\hline & Other & - & - & 1 & - \\
\hline \multicolumn{2}{|r|}{ Unidentified remains } & 113325 & 46275 & 472 & 8559 \\
\hline & Total & 122780 & 55449 & 11035 & 17727 \\
\hline
\end{tabular}

Table 2. Element distribution on the two sites according to the sector studied and the sieving mesh size (Chondr. $=$ Chondrichthyes). 
(A)

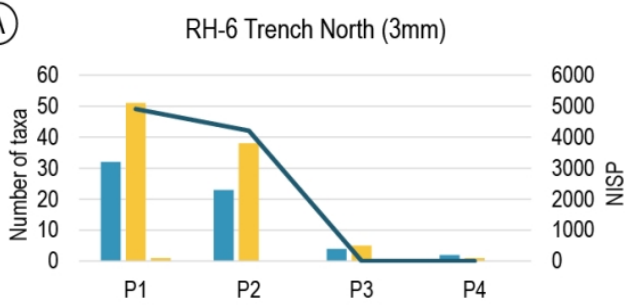

(B)

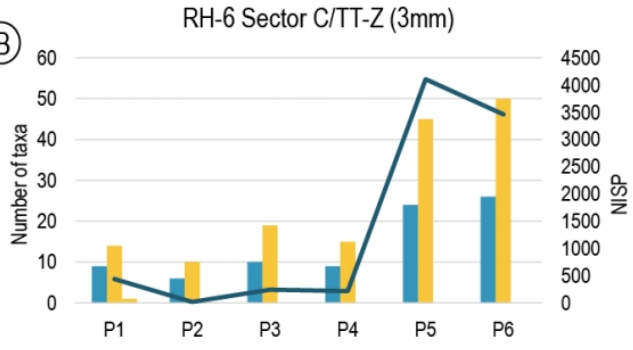

(C) RH-6 Sector C/TT Z (1mm)

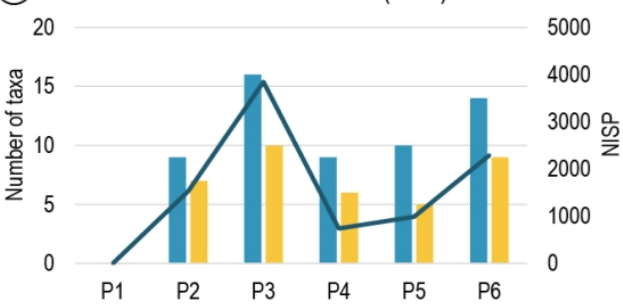

(D) $\mathrm{RH}-5$ Sector $\mathrm{B} 2(1 \mathrm{~mm})$

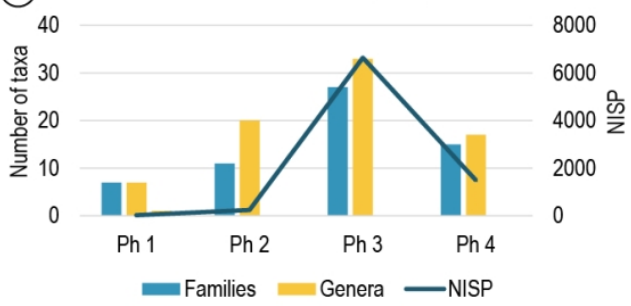

Figure 2. Taxonomic richness at family and genus levels for different sectors and time periods $233 \times 127 \mathrm{~mm}(150 \times 150 \mathrm{DPI})$ 
(A)

(B)

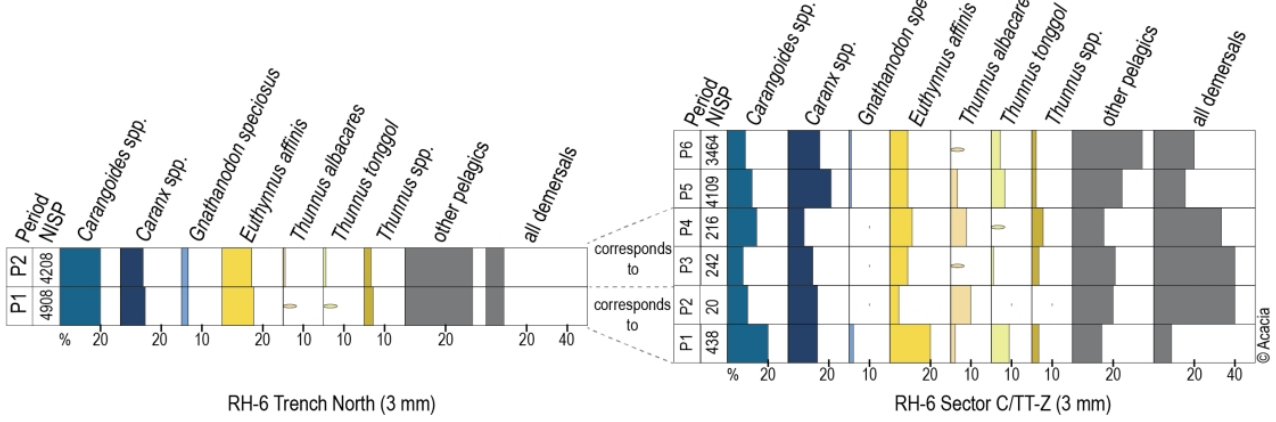

Figure 3. Illustration of the main taxa distribution (NISP).

(A) RH-6, Trench North, 3 mm; (B) RH-6, Sector C/TT-Z, 3 mm. Made with ACACIA (Nourissier, Nocus, and Dufraisse, 2010)

$214 \times 79 m m(300 \times 300$ DPI $)$ 


\begin{tabular}{|c|c|c|c|c|c|c|c|c|c|c|}
\hline & \multirow{2}{*}{ Main taxa } & \multicolumn{3}{|c|}{ Total Period 1} & \multicolumn{3}{|c|}{ Total Period 2} & \multicolumn{3}{|c|}{ Total } \\
\hline & & NISP & $\%$ & WISP & NISP & $\%$ & WISP & NISP & $\%$ & WISP \\
\hline \multirow{4}{*}{ 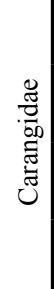 } & Carangoides spp. & 986 & 20.09 & 786.21 & 852 & 20.2 & 618.3 & 1838 & 20.2 & 1404.51 \\
\hline & Caranx spp. & 602 & 12.27 & 413.07 & 489 & 11.6 & 677.97 & 1091 & 12 & 1091.04 \\
\hline & Gnathanodon speciosus & 180 & 3.67 & 111.44 & 147 & 3.5 & 154.23 & 327 & 3.6 & $2,65.67$ \\
\hline & Other Carangidae & 1278 & 26.04 & 398.45 & 1079 & 25.6 & 409.43 & 2357 & 25.9 & 807.89 \\
\hline \multirow{5}{*}{ 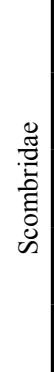 } & Euthynnus affinis & 775 & 15.79 & 506.04 & 609 & 14.5 & 377.02 & 1384 & 15.2 & 883.06 \\
\hline & Thunnus albacares & 21 & 0.43 & 14.07 & 73 & 1.7 & 47.05 & 94 & 1 & 61.13 \\
\hline & Thunnus tonggol & 4 & 0.08 & 2.48 & 47 & 1.1 & 24.01 & 51 & 0.6 & 26.48 \\
\hline & Thunnus spp. & 239 & 4.87 & 133.52 & 146 & 3.5 & 82.37 & 385 & 4.2 & 215.89 \\
\hline & Other Scombridae & 280 & 5.7 & 90.31 & 319 & 7.6 & 106.41 & 599 & 6.6 & 196.72 \\
\hline \multirow{4}{*}{$\begin{array}{l}\text { 节 } \\
\text { : } \\
\text { की }\end{array}$} & Other pelagic & 98 & 2 & 16.23 & 51 & 1.2 & 12.1 & 149 & 1.6 & 28.33 \\
\hline & Acanthopagrus spp. & 58 & 1.18 & 13.84 & 34 & 0.8 & 114.25 & 92 & 1 & 128.09 \\
\hline & Rhabdosargus spp. & 20 & 0.41 & 5.74 & 8 & 0.2 & 8.28 & 28 & 0.3 & 14.01 \\
\hline & Other Sparidae & 44 & 0.9 & 16.53 & 94 & 2.2 & 45.51 & 138 & 1.5 & 62.03 \\
\hline \multirow{2}{*}{ 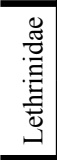 } & Lethrinus spp. & 80 & 1.63 & 19.18 & 110 & 2.6 & 23.75 & 190 & 2.1 & 42.93 \\
\hline & Other Lethrinidae & & & & 1 & 0 & 0.84 & 1 & 0 & 0.84 \\
\hline \multirow{3}{*}{ 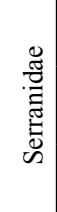 } & Cephalopholis spp. & 39 & 0.79 & 4.61 & 21 & 0.5 & 7.15 & 60 & 0.7 & 11.76 \\
\hline & Epinephelus spp. & 23 & 0.47 & 13.75 & 26 & 0.6 & 300.96 & 49 & 0.5 & 314.71 \\
\hline & Serranidae & 27 & 0.55 & 7.03 & 20 & 0.5 & 28.07 & 47 & 0.5 & 35.09 \\
\hline & Other demersal & 154 & 3.14 & 36.57 & 82 & 1.9 & 27.9 & 236 & 2.6 & 64.47 \\
\hline & Total pelagic & 4463 & & 2471.81 & 3812 & & 2508.9 & 8275 & & 4980.71 \\
\hline & Total demersal & 445 & & 117.24 & 396 & & 556.69 & 841 & & 673.94 \\
\hline & Unidentified fish & 80701 & & 13144.07 & 32906 & & 5685.25 & 113607 & & 18829.32 \\
\hline & TOTAL NISP & 4908 & 100 & 2589.05 & 4208 & 100 & 3065.59 & 9116 & 100 & 5654.64 \\
\hline
\end{tabular}

Table 3. Zooarchaeological fish remains from $\mathrm{RH}-6$, Trench North, $3 \mathrm{~mm}$, according to periods in NISP, \% of NISP and WISP (g) - Other pelagic (12 families; see Appendix), Other demersal (19 families; see Appendix) 


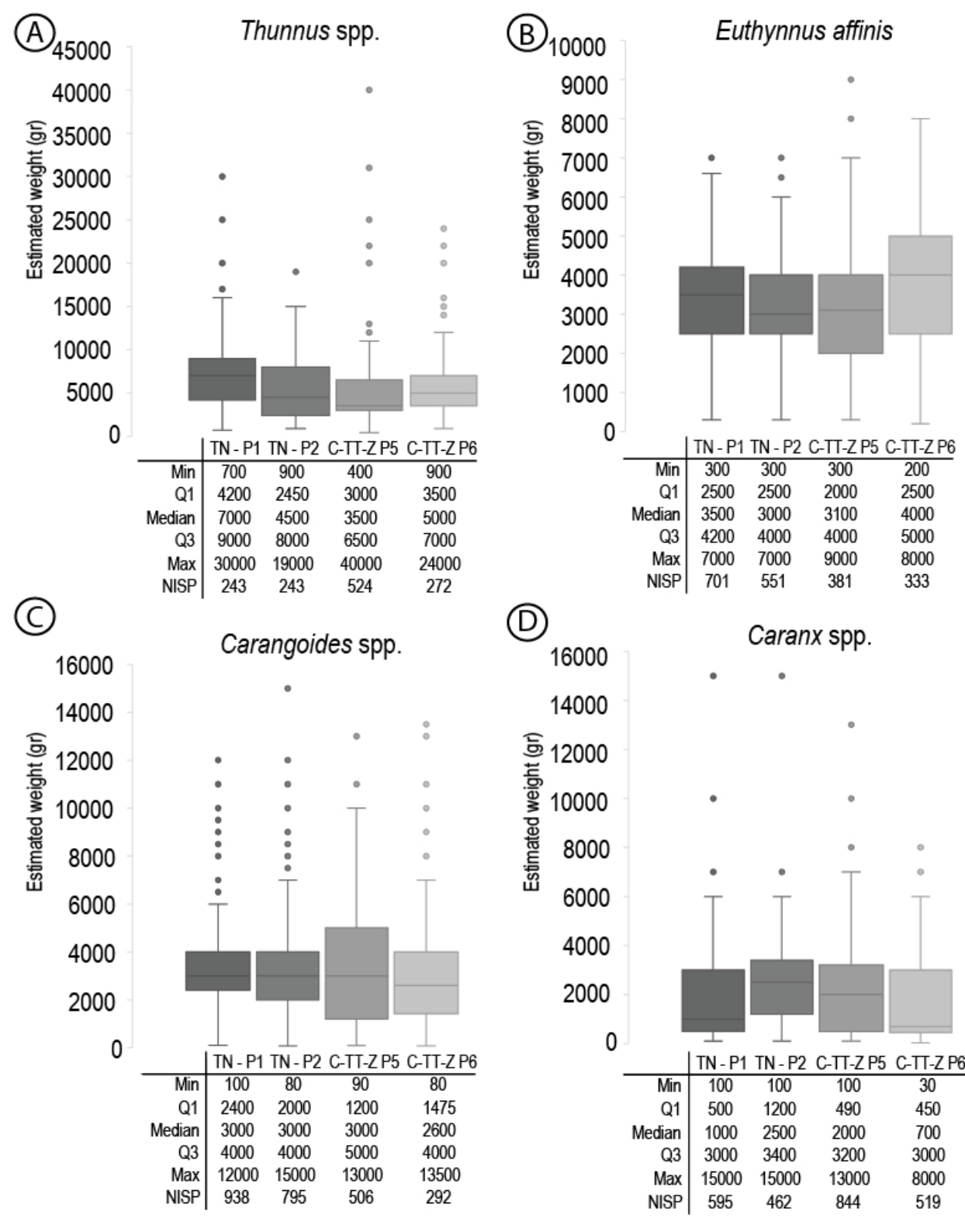

Figure 4. Illustration of the estimated weight of each main pelagic taxa from the richest RH-6 periods ( $\mathrm{P}$ : Period), both sectors (TN: Trench North, C-TTZ: Sector C TT-Z). Min: Minimum, Max: Maximum, Q:

Quartile. (A) Thunnus spp; (B) Euthynnus affinis; (C) Carangoides spp.; (D) Caranx spp.

$$
130 \times 165 \mathrm{~mm}(150 \times 150 \text { DPI })
$$




\begin{tabular}{|c|c|c|c|c|c|c|c|c|c|c|c|c|c|c|c|c|}
\hline \multirow{3}{*}{ Main taxa } & \multicolumn{4}{|c|}{ Trench North } & \multicolumn{12}{|c|}{ Sector C/TT-Z } \\
\hline & \multicolumn{2}{|c|}{ P1 } & \multicolumn{2}{|c|}{ P2 } & \multicolumn{2}{|c|}{ P1 } & \multicolumn{2}{|c|}{ P2 } & \multicolumn{2}{|c|}{ P3 } & \multicolumn{2}{|c|}{ P4 } & \multicolumn{2}{|c|}{ P5 } & \multicolumn{2}{|c|}{ P6 } \\
\hline & MNI & NISP & MNI & NISP & MNI & NISP & $\overline{M N I}$ & NISP & MNI & NISP & $\mathrm{MNI}$ & NISP & MNI & NISP & $\overline{M N I}$ & NISP \\
\hline Carangoides spp. & 180 & 986 & 168 & 852 & 39 & 92 & 1 & 2 & 9 & 19 & 14 & 32 & 109 & 527 & 68 & 308 \\
\hline Caranx spp. & 110 & 602 & 133 & 489 & 23 & 67 & 2 & 3 & 14 & 31 & 14 & 18 & 128 & 876 & 99 & 542 \\
\hline $\begin{array}{r}\text { Gnathanodon } \\
\text { speciosus }\end{array}$ & 35 & 180 & 35 & 147 & 9 & 13 & - & - & - & - & - & - & 22 & 62 & 18 & 50 \\
\hline Euthynnus affinis & 72 & 775 & 58 & 609 & 14 & 89 & 1 & 1 & 6 & 24 & 6 & 24 & 53 & 388 & 58 & $\overline{342}$ \\
\hline Thunnus albacares & 7 & 21 & 23 & 73 & 7 & 12 & 1 & 1 & 1 & 2 & 7 & 19 & 33 & 146 & 18 & 34 \\
\hline Thunnus tonggol & 1 & 4 & 8 & 47 & 12 & 43 & - & - & 3 & 4 & 1 & 1 & 34 & 312 & 28 & 168 \\
\hline Thunnus spp. & 34 & 239 & 23 & 146 & 2 & 15 & - & - & 5 & 10 & 5 & 12 & 7 & 111 & 5 & 92 \\
\hline Total & 439 & 2807 & 448 & 2363 & 106 & 331 & 5 & 7 & 38 & 90 & 47 & 106 & 386 & 2422 & 294 & 1536 \\
\hline
\end{tabular}

Table 4. MNI estimates of the main pelagic taxa at RH-6, $3 \mathrm{~mm}$, according to periods and comparison with the NISP. 


\begin{tabular}{|c|c|c|c|c|c|c|c|c|c|c|c|c|c|c|c|c|c|c|c|c|c|}
\hline \multirow{2}{*}{ Main taxa } & \multicolumn{3}{|c|}{ Period 1} & \multicolumn{3}{|c|}{ Period 2} & \multicolumn{3}{|c|}{ Period 3} & \multicolumn{3}{|c|}{ Period 4} & \multicolumn{3}{|c|}{ Period 5} & \multicolumn{3}{|c|}{ Period 6} & \multicolumn{3}{|c|}{ Total } \\
\hline & NISP & $\%$ & WISP & NISP & $\%$ & WISP & NISP & $\%$ & WISP & NISP & $\%$ & WISP & NISP & $\%$ & WISP & NISP & $\%$ & WISP & NISP & $\%$ & WISP \\
\hline Carangoides spp. & 92 & 21 & 65.12 & 2 & 10 & 0.59 & 19 & 7.9 & 6.49 & 32 & 14.8 & 38.77 & 527 & 12.8 & 316.49 & 308 & 8.9 & 1060.29 & 980 & 11.5 & 1487.75 \\
\hline Caranx spp. & 67 & 15.3 & 69.84 & 3 & 15 & 1.29 & 31 & 12.8 & 5.67 & 18 & 8.3 & 9.85 & 876 & 21.3 & 487.14 & 542 & 15.6 & 239.08 & 1537 & 18.1 & 812.87 \\
\hline nathanodon speciosus & 13 & 3 & 13.93 & & & & & & & & & & 62 & 1.5 & 49.16 & 50 & 1.4 & 41.32 & 125 & 1.5 & 104.41 \\
\hline Other Carangidae & 62 & 14.2 & 33.87 & 3 & 15 & 2.53 & 21 & 8.7 & 5.28 & 22 & 10.2 & 6.08 & 870 & 21.2 & 200.76 & 1086 & 31.4 & 682.25 & 2064 & 24.3 & 930.77 \\
\hline Euthynnus affinis & 89 & 20.3 & 58.56 & 1 & 5 & 0.24 & 24 & 9.9 & 8.38 & 24 & 11.1 & 7.37 & 388 & 9.4 & 252.34 & 342 & 9.9 & 271.25 & 868 & 10.2 & 598.13 \\
\hline Thunnus albacares & 12 & 2.7 & 6.82 & 2 & 10 & 1.62 & 2 & 0.8 & 0.4 & 19 & 8.8 & 9.92 & 146 & 3.6 & 73.67 & 34 & 1 & 18.62 & 215 & 2.5 & 111.05 \\
\hline Thunnus tonggol & 43 & 9.8 & 20.83 & & & & 4 & 1.7 & 2.07 & 1 & 0.5 & 0.73 & 312 & 7.6 & 134.48 & 168 & 4.8 & 103.21 & 528 & 6.2 & 261.33 \\
\hline Thunnus spp. & 15 & 3.4 & 9.58 & & & & 10 & 4.1 & 3.61 & 12 & 5.6 & 3.89 & 111 & 2.7 & 341.48 & 92 & 2.7 & 49.39 & 240 & 2.8 & 407.94 \\
\hline Other Scombridae & 2 & 0.5 & 0.48 & & & & 9 & 3.7 & 1.56 & 11 & 5.1 & 2.07 & 79 & 1.9 & 30.92 & 99 & 2.9 & 17.71 & 200 & 2.4 & 52.73 \\
\hline Other pelagic & 4 & 0.9 & 1.96 & 1 & 5 & 0.03 & 23 & 9.5 & 2.04 & 3 & 1.4 & 1.56 & 89 & 2.2 & 11.13 & 30 & 0.9 & 10.72 & 150 & 1.8 & 27.45 \\
\hline 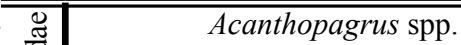 & $\overline{6}$ & $\overline{1.4}$ & $\bar{~} 6.47$ & $\overline{\overline{1}}$ & $\overline{5}$ & $\overline{0.26}$ & $\overline{30}$ & $\overline{12.4}$ & $\overline{5.13}$ & $\overline{8}$ & \begin{tabular}{c|}
3.7 \\
\end{tabular} & 1.29 & $\overline{127}$ & 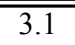 & 25.99 & $\overline{136}$ & $\begin{array}{c}3.9 \\
\end{array}$ & 13.46 & $\overline{2308}$ & 3.6 & $\overline{52.6}$ \\
\hline Rhabdosargus spp. & 3 & 0.7 & 1.06 & 2 & 10 & 0.54 & 19 & 7.9 & 6.4 & 13 & 6 & 5.36 & 23 & 0.6 & 10.87 & 14 & 0.4 & 6.73 & 74 & 0.9 & 30.97 \\
\hline Other Sparidae & 2 & 0.5 & 0.75 & 3 & 15 & 0.31 & 8 & 3.3 & 1.76 & 8 & 3.7 & 0.53 & 41 & 1 & 14.23 & 53 & 1.5 & 10.01 & 115 & 1.4 & 27.6 \\
\hline Lethrinus spp. & 16 & 3.7 & 5.36 & 1 & 5 & 0.05 & 20 & 8.3 & 2.32 & 16 & 7.4 & 3.38 & 218 & 5.3 & 41.79 & 208 & 6 & 27.23 & 479 & 5.6 & 80.13 \\
\hline Cephalopholis spp. & $\overline{3}$ & 0.7 & 0.73 & \multirow{3}{*}{1} & \multirow{3}{*}{$5 . .0$} & \multirow{3}{*}{0.21} & 5 & 2.1 & 1.32 & 13 & $\overline{6}$ & 2.17 & 42 & 1 & 6.95 & 66 & 1.9 & 17.85 & 129 & 1.5 & 29.01 \\
\hline Epinephelus spp. & 4 & 0.9 & 1.88 & & & & 7 & 2.9 & 0.9 & 1 & 0.5 & 0.12 & 62 & 1.5 & 11.59 & 61 & 1.8 & 16.23 & 136 & 1.6 & 30.94 \\
\hline Other Serranidae & 2 & 0.5 & 0.81 & & & & 3 & 1.2 & 0.18 & 6 & 2.8 & 0.66 & 14 & 0.3 & 2.22 & 32 & 0.9 & 6.2 & 57 & 0.7 & 10.06 \\
\hline Other demersal & 3 & 0.7 & 1.53 & & & & 7 & 2.9 & 1.03 & 9 & 4.2 & 6.49 & 122 & 3 & 34.19 & 143 & 4.1 & 22.12 & 284 & 3.3 & 65.36 \\
\hline Total pelagic & 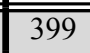 & & 280.97 & $\overline{12}$ & & 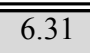 & 143 & & 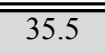 & 142 & & 80.24 & 3460 & & 1897.57 & 2751 & & 2493.83 & 6907 & & $\overline{47794.42}$ \\
\hline Total demersal & 39 & & 18.6 & 8 & & 1.37 & 99 & & 19.05 & 74 & & 19.99 & 649 & & 147.84 & 713 & & 119.83 & 1582 & & 326.66 \\
\hline Unidentified fish & & & & 942 & & 51.7 & 1336 & & 96.17 & 1120 & & 103.96 & 18337 & & 2831.27 & 25225 & & 3262.15 & 46960 & & 6345.25 \\
\hline TOTAL NISP & 438 & 100 & 299.569 & 20 & 100 & 7.65 & 242 & 100 & 54.549 & 216 & 100 & 100.22 & 4109 & 100 & 2045.4 & 3464 & 100 & 2613.67 & 8489 & 100 & 5121.09 \\
\hline
\end{tabular}

Table 5. Zooarchaeological fish remains from RH-6, Sector C/TT-Z, $3 \mathrm{~mm}$, according to periods in NISP, \% of NISP and WISP (g) - Other pelagic (5 families; see Appendix),

Other demersal (24 families; see Appendix) 


\begin{tabular}{|c|c|c|c|c|c|c|c|c|c|c|c|c|}
\hline \multirow{2}{*}{ Main taxa } & \multicolumn{2}{|c|}{ Period 2} & \multicolumn{2}{|c|}{ Period 3} & \multicolumn{2}{|c|}{ Period 4} & \multicolumn{2}{|c|}{ Period 5} & \multicolumn{2}{|c|}{ Period 6} & \multicolumn{2}{|c|}{ Total } \\
\hline & NISP & $\%$ & NISP & $\%$ & NISP & $\%$ & NISP & $\%$ & NISP & $\%$ & NISP & $\%$ \\
\hline Clupeidae & 691 & 45.2 & 2486 & 64.7 & 539 & 72.8 & 825 & 83.4 & 1600 & 69.9 & 6141 & 65.4 \\
\hline Carangidae & 452 & 29.6 & 822 & 21.4 & 85 & 11.5 & 90 & 9.1 & 274 & 12.0 & 1723 & 18.4 \\
\hline Atherinidae & 212 & 13.9 & 155 & 4.0 & 34 & 4.6 & 9 & 0.9 & 237 & 10.4 & 647 & 6.9 \\
\hline Mugilidae & 98 & 6.4 & 158 & 4.1 & 17 & 2.3 & 3 & 0.3 & 31 & 1.4 & 307 & 3.3 \\
\hline Other pelagic & 1 & 0.1 & 6 & 0.2 & 44 & 5.9 & 22 & 2.2 & 35 & 1.5 & 108 & 1.2 \\
\hline Sparoidea & 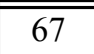 & 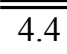 & 194 & 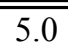 & 13 & 1.8 & 36 & 3.6 & 97 & 4.2 & 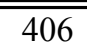 & 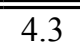 \\
\hline Other demersal & 8 & 0.5 & 21 & 0.5 & 8 & 1.1 & 4 & 0.4 & 15 & 0.7 & 56 & 0.6 \\
\hline Total pelagic & 1454 & & 3627 & & 719 & & 949 & & 2177 & & 8926 & \\
\hline Total demersal & 75 & & 215 & & 21 & & 40 & & 112 & & 462 & \\
\hline Unidentified fish & 224 & & 417 & & 399 & & 139 & & 468 & & 1647 & \\
\hline Total NISP & 1529 & 100 & 3842 & 100 & 740 & 100 & 989 & 100 & 2289 & 100 & 9388 & 100 \\
\hline
\end{tabular}

Table 6. Zooarchaeological fish remains from RH-6, Sector C/TT-Z, $1 \mathrm{~mm}$, according periods in NISP and \% of NISP. Other pelagic ( 9 families; see Appendix),

Other demersal (13 families; see Appendix) 


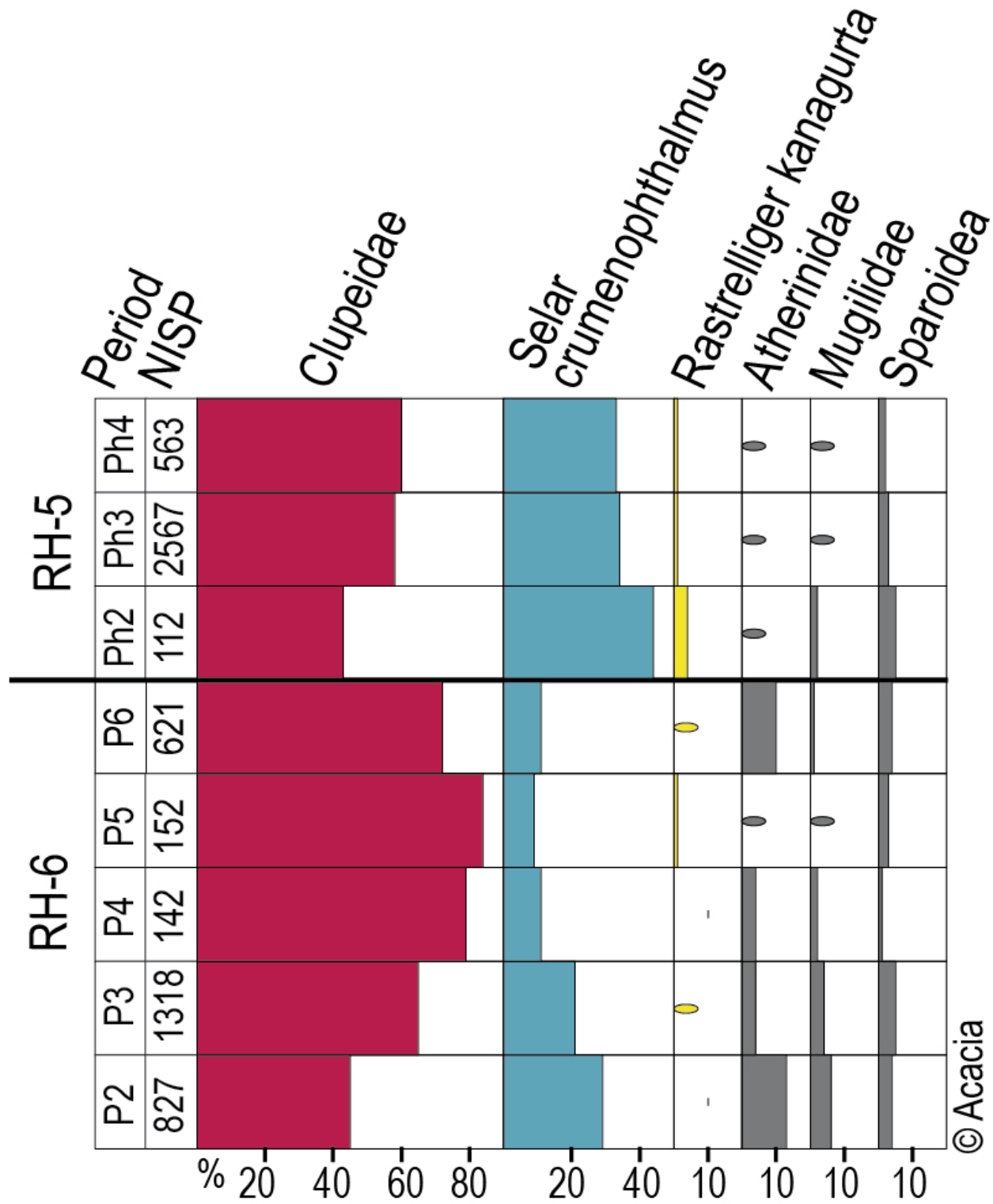

Figure 5. Illustration of the main taxa distribution (NISP).

RH-6, Sector C/TT-Z, 1 mm (Periods 2, 3, 4, 5, 6) - RH-5, Sector B2, $1 \mathrm{~mm}$ (Phases 2, 3, 4). Made with ACACIA (Nourissier, Nocus, and Dufraisse, 2010)

$68 \times 84 \mathrm{~mm}(300 \times 300$ DPI $)$ 


\begin{tabular}{|c|c|c|c|c|c|c|c|c|c|c|c|c|c|c|c|c|}
\hline \multirow{2}{*}{\multicolumn{2}{|c|}{ Taxa }} & \multicolumn{3}{|c|}{ Phase 1} & \multicolumn{3}{|c|}{ Phase 2} & \multicolumn{3}{|c|}{ Phase 3} & \multicolumn{3}{|c|}{ Phase 4} & \multicolumn{3}{|c|}{ Total } \\
\hline & & NISP & $\%$ & WISP & NISP & $\%$ & WISP & NISP & $\%$ & WISP & NISP & $\%$ & WISP & NISP & $\%$ & WISP \\
\hline & Clupeidae & 3 & 9.4 & 0.00 & 85 & 35.1 & 0.18 & 3668 & 55.2 & 9.92 & 863 & 57.8 & 2 & 4619 & 54.9 & 12.10 \\
\hline \multirow{5}{*}{ 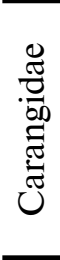 } & Carangoides spp. & & & & 2 & 0.8 & 1.49 & 8 & 0.1 & 2.55 & 1 & 0.1 & 0.01 & 11 & 0.1 & 4.13 \\
\hline & Caranx spp. & 1 & 3.1 & 7.47 & 4 & 1.7 & 0.43 & 31 & 0.5 & 11.61 & 0 & 0.0 & 0 & 36 & 0.4 & 19.52 \\
\hline & $\begin{array}{r}\text { Selar } \\
\text { crumenophthalmus }\end{array}$ & 8 & 25.0 & 0.06 & 88 & 36.4 & 0.43 & 2175 & 32.8 & 10.66 & 484 & 32.4 & 1.99 & 2755 & 32.8 & 13.14 \\
\hline & Trachurus indicus & & & & 5 & 2.1 & 0.05 & 61 & 0.9 & 0.31 & 17 & 1.1 & 0.08 & 83 & 1.0 & 0.44 \\
\hline & Other Carangidae & 5 & 15.6 & 0.45 & 9 & 3.7 & 0.95 & 97 & 1.5 & 7.1 & 14 & 0.9 & 1.56 & 125 & 1.5 & 10.06 \\
\hline \multirow{14}{*}{ 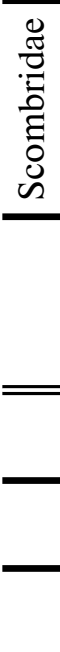 } & Auxis thazard & 2 & 6.3 & 0.1 & & & & 12 & 0.2 & 1.03 & 3 & 0.2 & 0.07 & 17 & 0.2 & 1.20 \\
\hline & Euthynnus affinis & & & & 8 & 3.3 & 2.31 & 34 & 0.5 & 6.66 & 3 & 0.2 & 0.98 & 45 & 0.5 & 9.95 \\
\hline & Rastrelliger kanagurta & 3 & 9.4 & 0.06 & 8 & 3.3 & 0.15 & 109 & 1.6 & 2.06 & 24 & 1.6 & 0.18 & 144 & 1.7 & 2.45 \\
\hline & Other Scombridae & & & & 3 & 1.2 & 0.63 & 10 & 0.2 & 3.1 & 1 & 0.1 & 0.26 & 14 & 0.2 & 3.99 \\
\hline & Mugilidae & 1 & 3.1 & 0.03 & 5 & 2.1 & 0.1 & 45 & 0.7 & 0.51 & 13 & 0.9 & 0.11 & 64 & 0.8 & 0.75 \\
\hline & Atherinidae & & & & 1 & 0.4 & 0 & 13 & 0.2 & 0.01 & 4 & 0.3 & 0 & 18 & 0.2 & 0.01 \\
\hline & Sphyraenidae & & & & 3 & 1.2 & 0.52 & 43 & 0.6 & 0.69 & 7 & 0.5 & 0.08 & 53 & 0.6 & 1.29 \\
\hline & Other pelagic & & & & & & 0 & 13 & 0.2 & 0.31 & & 0.0 & & 13 & 0.2 & 0.31 \\
\hline & Sparoidea & 8 & 25.0 & 0.47 & 10 & 4.1 & 0.57 & 225 & 3.4 & 5.91 & 38 & 2.5 & 1.37 & 281 & 3.3 & 8.32 \\
\hline & Other demersal & 1 & 3.1 & 0.04 & 11 & 4.5 & 0.51 & 96 & 1.4 & 4.15 & 20 & 1.3 & 0.18 & 128 & 1.5 & 4.89 \\
\hline & Total pelagic & 23 & & 8.17 & 221 & & 7.24 & 6319 & & 56.52 & 1434 & & 7.32 & 7997 & & 79.34 \\
\hline & Total demersal & 9 & & 0.51 & 21 & & 1.08 & 321 & & 10.06 & 58 & & 1.55 & 409 & & 13.21 \\
\hline & Unidentified fish & 91 & & 4.90 & 608 & & 26.78 & 7251 & & 192.53 & 1371 & & 31.80 & 9321 & & 256.00 \\
\hline & Total NISP & 32 & 100 & 8.68 & 242 & 100 & 8.32 & 6640 & 100 & 66.58 & 1492 & 100 & 8.87 & 8406 & 100 & 92.55 \\
\hline
\end{tabular}

Table 7. Zooarchaeological fish remains from RH-5, Sector B2, $1 \mathrm{~mm}$, according to periods in NISP, \% of NISP and WISP (g)

- Other pelagic (7 families; see Appendix), Other demersal (20 families; see Appendix) 

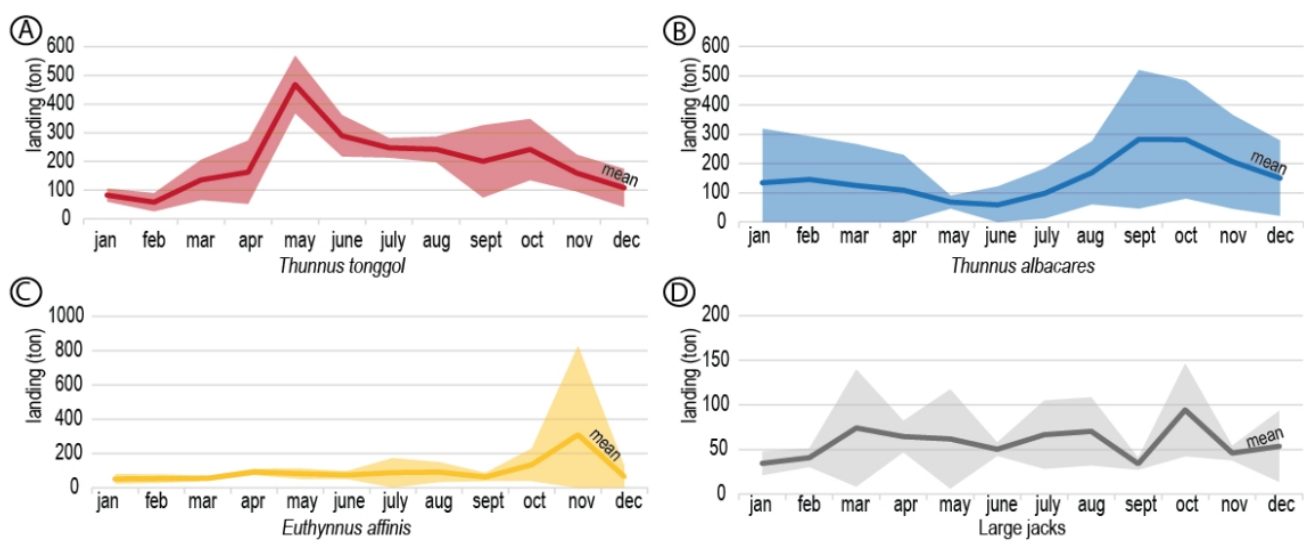

Figure 6. Compiled data (in metric tons) for 4 years $(2013,2015,2016,2018)$ of artisanal fisheries in Muscat governorate for Thunnus tonggol, Thunnus albacares, Euthynnus affinis, and large jacks (Carangidae) (M.A.F. 2013, 2015, 2016, 2018). The thick line represents the mean. The filled area is the standard deviation of the mean

$199 \times 81 \mathrm{~mm}(150 \times 150 \mathrm{DPI})$ 


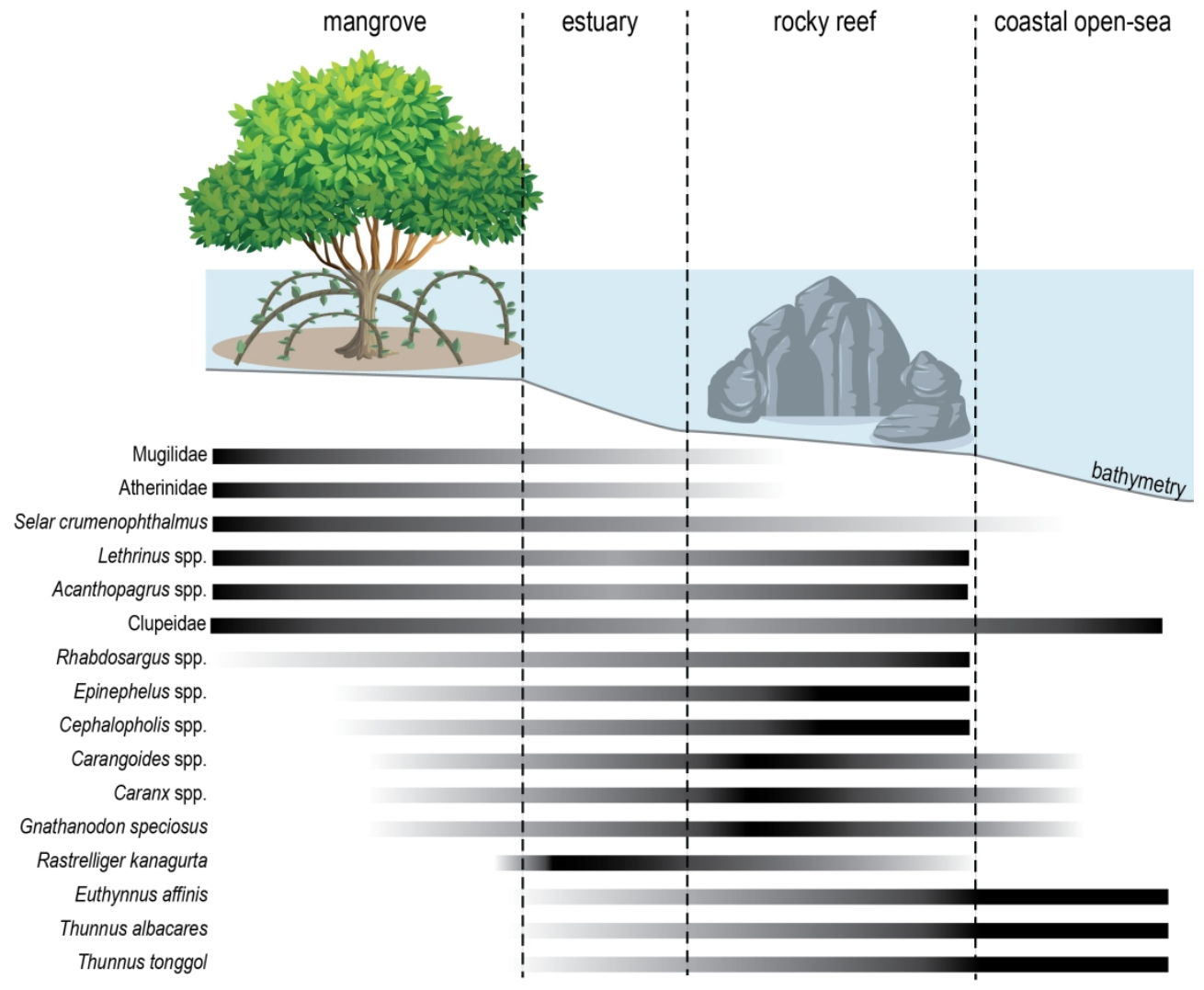

Figure 7. Ecological distribution of the main taxa found at both sites according to Froese and Pauly (2021), Randall (1995) and personal observations. Vector objects are from Vecteezy.com (Graphics RF)

$178 \times 147 \mathrm{~mm}(300 \times 300 \mathrm{DPI})$ 


\begin{tabular}{|c|c|c|c|c|c|c|}
\hline Higher taxa & Genus/Species & 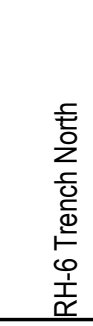 & 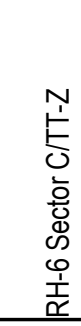 & 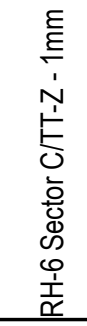 & 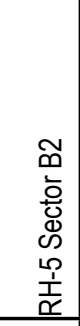 & 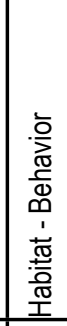 \\
\hline Selachimorpha & & & & & 2 & $P$ \\
\hline Carcharhinidae & & 5 & & 1 & & $P$ \\
\hline Batoidea & & & 1 & 2 & & $\mathrm{D}$ \\
\hline Dasyatidae & & 1 & 2 & & & $D$ \\
\hline Albulidae & Albula sp. & & 2 & & & D \\
\hline \multirow[t]{2}{*}{ Muraenidae } & & 3 & & & & $B$ \\
\hline & Gymnothorax spp. & 5 & 5 & & & B \\
\hline Ophichthidae & & 2 & & & 1 & $B$ \\
\hline Clupeidae & & 5 & & 6141 & 4619 & EP \\
\hline Engraulidae & & & & 49 & & $P$ \\
\hline Chirocentridae & Chirocentrus nudus & 2 & 4 & 1 & & $\mathrm{P}$ \\
\hline Pristigasteridae & Ilisha compressa & & & 31 & 1 & $P$ \\
\hline Silluriformes & & & & 1 & & $B$ \\
\hline Plotosidae & & & & 11 & & B \\
\hline \multirow[t]{4}{*}{ Ariidae } & & 13 & 3 & & 3 & $\mathrm{D}$ \\
\hline & Netuma bilineata & & 3 & & 1 & $\mathrm{D}$ \\
\hline & Netuma spp. & 10 & 5 & & & $D$ \\
\hline & Plicofolis spp. & 2 & & & 1 & $\mathrm{D}$ \\
\hline Holocentridae & Sargocentron sp. & & 4 & & & $\mathrm{D}$ \\
\hline Stromateidae & Pampus argenteus & 1 & & & & EP \\
\hline Pomatomidae & Pomatomus saltatrix & 1 & & & & $P$ \\
\hline \multirow[t]{11}{*}{ Scombridae } & & 435 & 118 & & 8 & $P$ \\
\hline & Auxis thazard & 53 & 14 & & 17 & $\mathrm{P}$ \\
\hline & Euthynnus affinis & 1384 & 868 & & 45 & $P$ \\
\hline & Katsuwonus pelamis & 82 & 42 & & & $P$ \\
\hline & Rastrelliger kanagurta & 27 & 17 & 22 & 144 & $P$ \\
\hline & Sarda orientalis & 1 & 2 & & 2 & $P$ \\
\hline & Scomber australasicus & & 4 & & & $P$ \\
\hline & Scomberomorus commerson & 1 & 3 & & & $P$ \\
\hline & Thunnus albacares & 94 & 215 & & & $P$ \\
\hline & Thunnus tonggol & 51 & 528 & & & $P$ \\
\hline & Thunnus spp. & 385 & 240 & & 4 & $P$ \\
\hline Trichiuridae & Trichiurus sp. & 1 & & & & $P$ \\
\hline \multirow[t]{5}{*}{ Sphyraenidae } & Sphyraena acutipinnis & & 3 & & & $P$ \\
\hline & Sphyraena jello & & 10 & & & $P$ \\
\hline & Sphyraena putnamae & 3 & 4 & & & $P$ \\
\hline & Sphyraena qenie & 1 & & & & $P$ \\
\hline & Sphyraena spp. & 81 & 97 & 2 & 53 & $P$ \\
\hline Polynemidae & Eleutheronema tetradactylum & & & & 1 & $D$ \\
\hline Paralichthyidae & Pseudorhombus sp. & 1 & & & & $\mathrm{P}$ \\
\hline
\end{tabular}




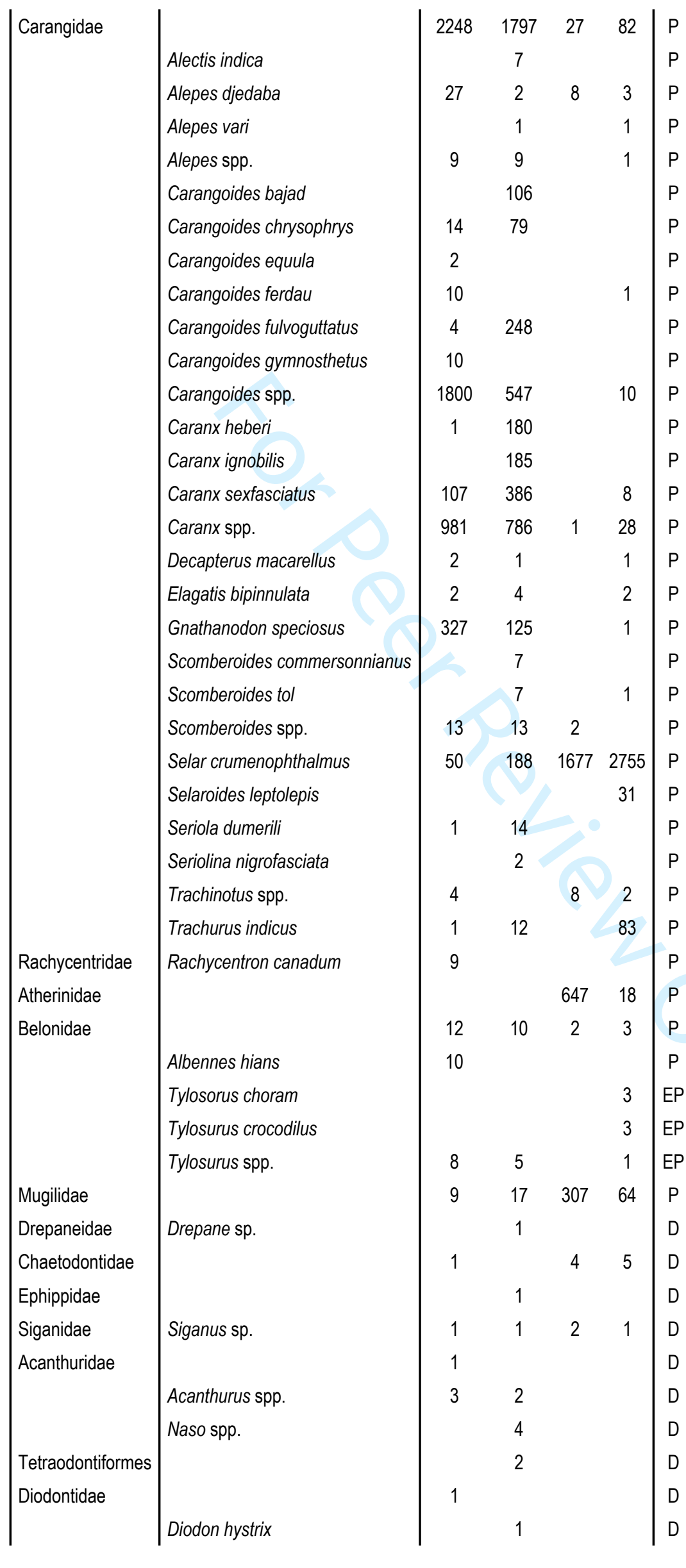




\begin{tabular}{|c|c|c|c|c|c|c|}
\hline Tertraodontidae & & & 1 & & & $D$ \\
\hline \multirow[t]{6}{*}{ Balistidae } & & 6 & 4 & & 1 & $\mathrm{D}$ \\
\hline & Abalistes stellatus & & 1 & & & $\mathrm{D}$ \\
\hline & Balistoides viridescens & 1 & 1 & & & $\mathrm{D}$ \\
\hline & Canthidermis macrolepis & & 1 & & & $\mathrm{D}$ \\
\hline & Odonus niger & 1 & & & & $\mathrm{D}$ \\
\hline & Sufflamen fraenatum & 5 & 33 & & & $\mathrm{D}$ \\
\hline Terapontidae & Terapon jarbua & 12 & 8 & 1 & 4 & $\mathrm{D}$ \\
\hline Ambassidae & & & & 15 & & D \\
\hline \multirow[t]{10}{*}{ Serranidae } & & 47 & 56 & 7 & 8 & J \\
\hline & Cephalopholis hemistiktos & 1 & 22 & & & $\mathrm{D}$ \\
\hline & Cephalopholis sexmaculata & 2 & 23 & & & כ) \\
\hline & Cephalopholis spp. & 57 & 84 & 1 & 5 & $\mathrm{D}$ \\
\hline & Epinephelus coioides & & 1 & & & D \\
\hline & Epinephelus diacanthus & 1 & 2 & & & D \\
\hline & Epinephelus radiatus & & 3 & & & D \\
\hline & Epinephelus stoliczkae & 4 & 6 & & & D \\
\hline & Epinephelus spp. & 44 & 124 & & 5 & $\mathrm{D}$ \\
\hline & Plectropomus sp. & & 1 & & & $\mathrm{D}$ \\
\hline Apogonidae & Apogon sp. & 1 & & & & D \\
\hline Sillaginidae & Sillago spp. & 1 & & 6 & 6 & $\mathrm{D}$ \\
\hline \multirow[t]{5}{*}{ Lutjanidae } & Lutjanus coeruleolineatus & & 6 & & & $\mathrm{D}$ \\
\hline & Lutjanus ehrenbergii & & 5 & & & \\
\hline & Lutjanus fulviflamma & & 4 & & & D \\
\hline & Lutjanus indicus & & 2 & & & D \\
\hline & Lutjanus spp. & 10 & 38 & 3 & 49 & D \\
\hline Caesionidae & Caesio sp. & & & & 1 & D \\
\hline Gerreidae & Gerres spp. & 2 & & 3 & 13 & D \\
\hline \multirow[t]{8}{*}{ Haemulidae } & & 10 & & & 4 & D \\
\hline & Plectorhinchus gaterinus & & 2 & & & D \\
\hline & Plectorhinchus pictus & & 3 & & & $D$ \\
\hline & Plectorhinchus schotaf & & 2 & & & ป \\
\hline & Plectorhinchus spp. & 8 & 26 & & 1 & $\mathrm{D}$ \\
\hline & Pomadasys argenteus & & 4 & & & D \\
\hline & Pomadasys commersonnii & & 1 & & & $D$ \\
\hline & Pomadasys spp. & 52 & 33 & & 12 & U \\
\hline Sparoidea & & 23 & 43 & 265 & 179 & $D$ \\
\hline \multirow[t]{8}{*}{ Sparidae } & & 80 & 94 & 130 & 37 & U \\
\hline & Acanthopagrus bifasciatus & 1 & 6 & & & U \\
\hline & Acanthopagrus spp. & 91 & 302 & & 21 & U \\
\hline & Argyrops spinifer & 20 & 14 & & & \\
\hline & Argyrops spp. & 35 & 2 & & & \\
\hline & Rhabdosargus haffara & & 23 & & & \\
\hline & Rhabdosargus spp. & 28 & 51 & & 1 & R \\
\hline & Sparidentex hasta & 3 & 5 & & & \\
\hline Lethrinidae & Gnathodentex aureolineatus & 1 & & & & \\
\hline
\end{tabular}




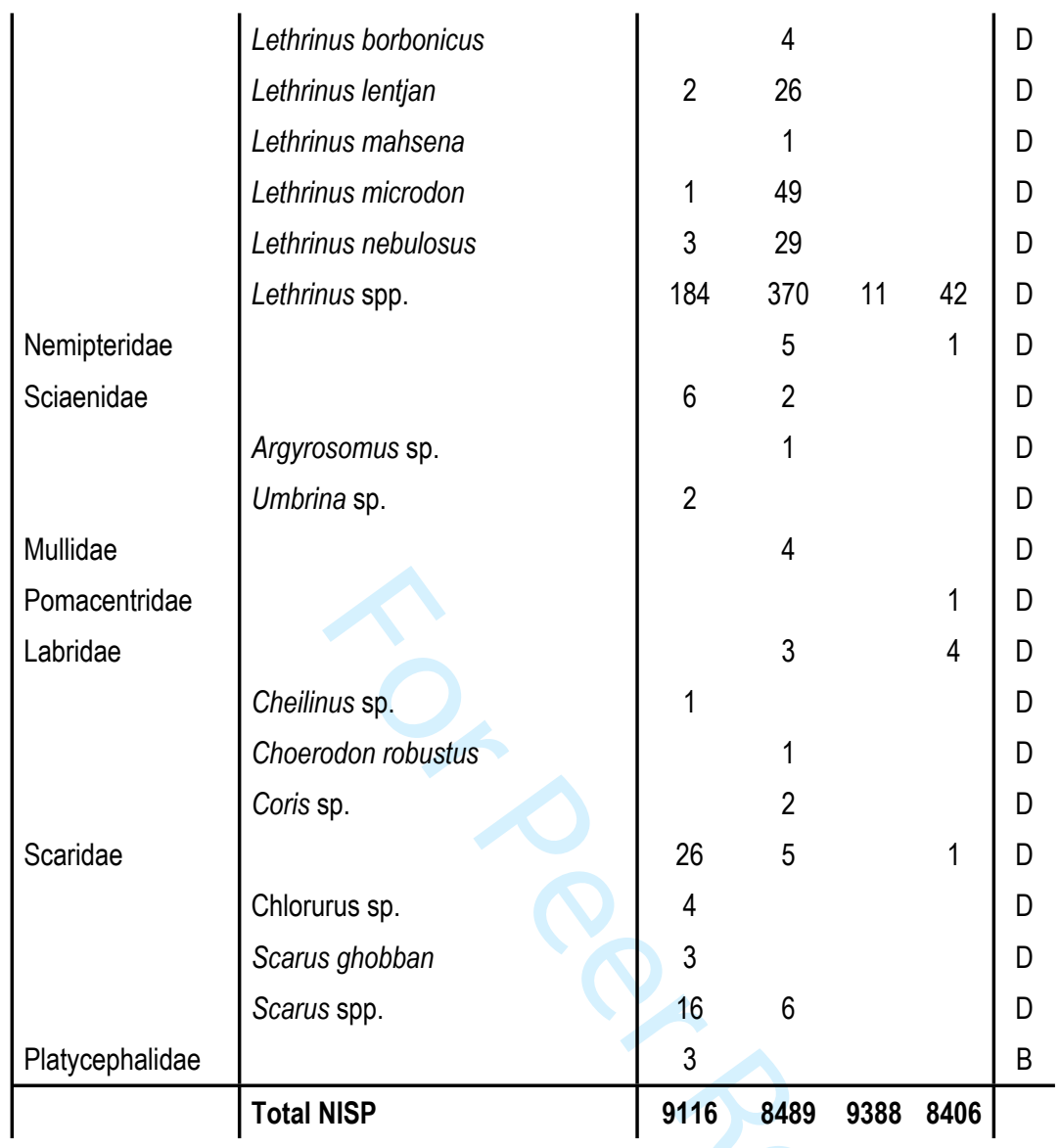

Supplemental file 1. List and NISP of taxa recovered at RH-6 and RH-5, arranged in taxonomic order. B: benthic; D: demersal; EP: epipelagic; P: pelagic. For fish behaviour, we followed the information from Randall (1995) and FishBase (Froese and Pauly 2021). 


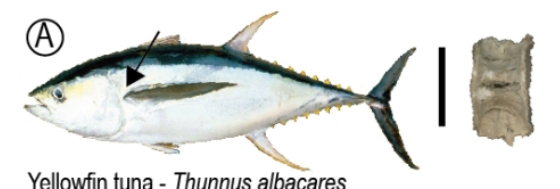

scale: $1 \mathrm{~cm}$

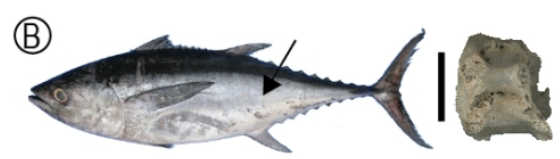

Yellowfin tuna - Thunnus albacares

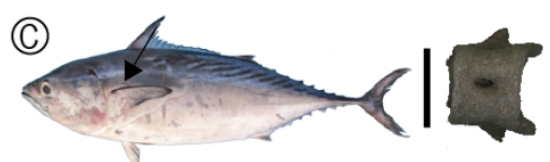

Kawakawa - Euthynnus affinis

(B)

Longtail tuna - Thunnus tonggol

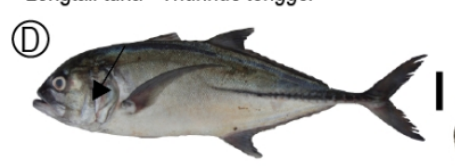

Bigeye trevally - Caranx sexfasciatus
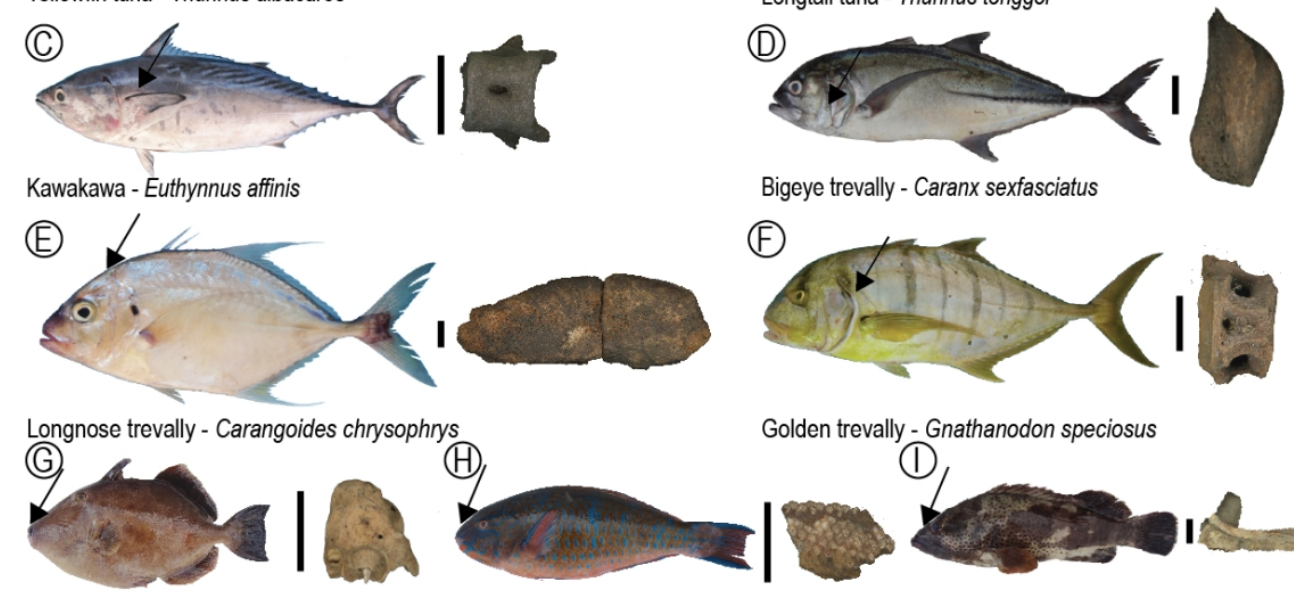

Golden trevally - Gnathanodon speciosus

Bridled TriggerFish - Suflamen fraenatum

Parrotfish - Scarus sp.

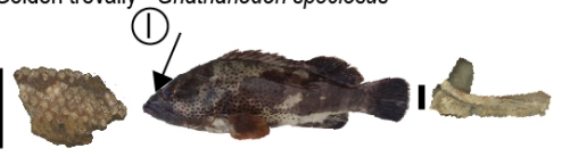

Grouper - Epinephelus sp.

(J)

(《)

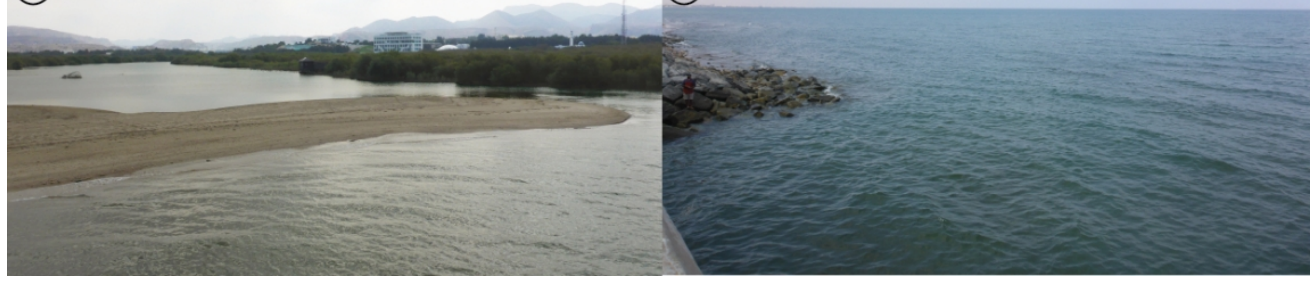

$210 \times 185 \mathrm{~mm}(150 \times 150 \mathrm{DPI})$ 


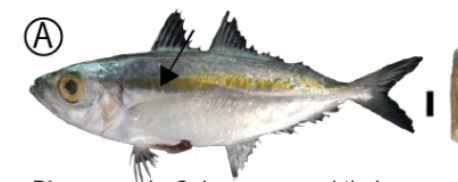

Bigeye scad - Selar crumenophthalmus

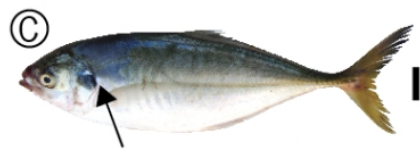

Shrimp scad - Alepes djedaba

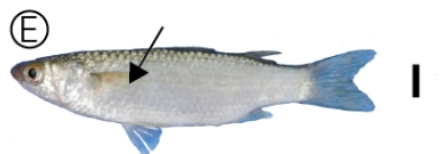

Mullet - Mugilidae scale: $1 \mathrm{~mm}$ (B)

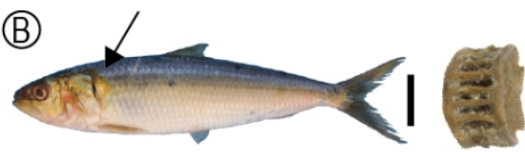

Sardine - Clupeidae (cf. Sardinella longiceps)

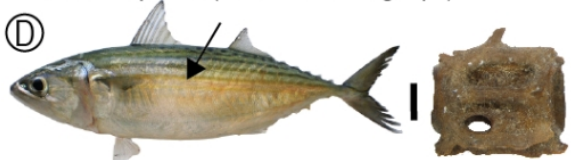

Indian mackerel - Rastrelliger kanagurta

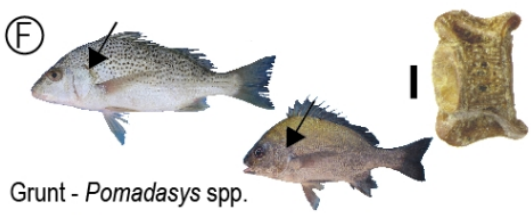

Grunt - Pomadasys spp.

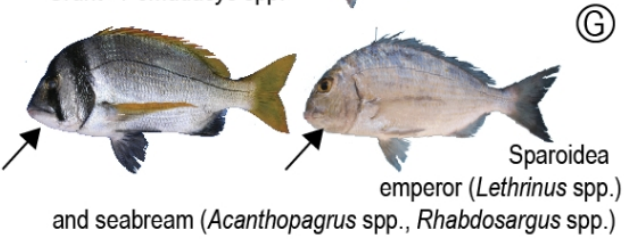

(H)

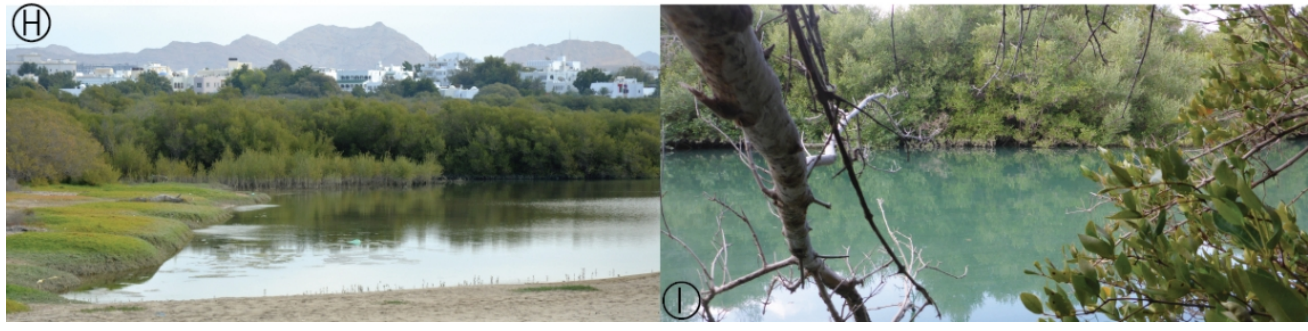

$204 \times 184 \mathrm{~mm}(150 \times 150 \mathrm{DPI})$ 